Chapter 24

\title{
Valorisation of Cheese Whey, a By-Product from the Dairy Industry
}

\author{
Chiara Mollea, Luca Marmo and Francesca Bosco \\ Additional information is available at the end of the chapter \\ http://dx.doi.org/10.5772/53159
}

\section{Introduction}

Whey is the by-product of cheese or casein production, it is of relative importance in the dairy industry due to the large volumes produced and the nutritional composition. Worldwide whey production is estimated at around 180 to $190 \times 10^{6}$ ton/year; of this amount only $50 \%$ is processed [1]. Approximately $50 \%$ of worldwide cheese-whey $(\mathrm{CW})$ production is treated and transformed into various food and feed products. About half of this amount is used directly in liquid form, $30 \%$ as powdered cheese-whey, $15 \%$ as lactose and its byproducts and the rest as cheese whey- protein concentrates [2].

A total of $40 \times 10^{6}$ tons/year of whey is produced in the European Union [3]; the annual surplus of whey is $13 \times 10^{6}$ tons, containing about 619,250 tons of lactose. Nowadays this surplus is not utilized for further production of lactose; consequently, whey disposal represents a serious problem from both an economical and an environmental point of view. On the contrary, recovery of whey components and/or use of whey as fermentation medium may be advantageous not only for the environment but also for a sustainable economy $[4,5]$.

Whey contains more than half of the solids present in the original whole milk, including whey proteins ( $20 \%$ of the total protein) and most of the lactose, water-soluble vitamins and minerals. Consequently, whey can be considered a valuable by-product with several applications in the food and pharmaceutical industries.

From a valorization point of view, two different options in CW management can be considered: the first one is based on the application of technologies to recover valuable compounds such as proteins and lactose. Currently, valorization processes applied to CW constitute the preferential option to treat this by-product, only exceeded by the production of powdered $\mathrm{CW}$. The second option relies on the application of fermentation processes to obtain value 
added products [6] such as: organic acids (e.g. lactic, succinic and propionic), single cell proteins and oils, biopolymers (enzymes, polyhydroxyalkanoates, exopolysaccharides) and bacteriocins. Sometimes whey permeate, obtained from ultrafiltration step, has been used as fermentation medium; in this case, both the management options are applied.

The ultrafiltration process produces a whey permeate rich in lactose (about $80 \%$ of the original lactose in milk) new technologies have been developed (using nanofiltration or reverse osmosis) for concentration of the lactose which can be applied in the sweet industry or in pharmaceutical fermentation procedures [7]. In addition to lactose, whey permeate containing other nutrients essential for microbial growth; so the possibility to use it as a fermentation medium to obtain high value products represents an interesting opportunity [4] which must not be neglected. Moreover, whey permeate is an attractive source of oligosaccharides for potential application in human nutrition [8].

Among the different possibility of whey valorization, reported in Figure 1, individual whey protein purification and application of fermentation technology on whey permeate will be discussed.

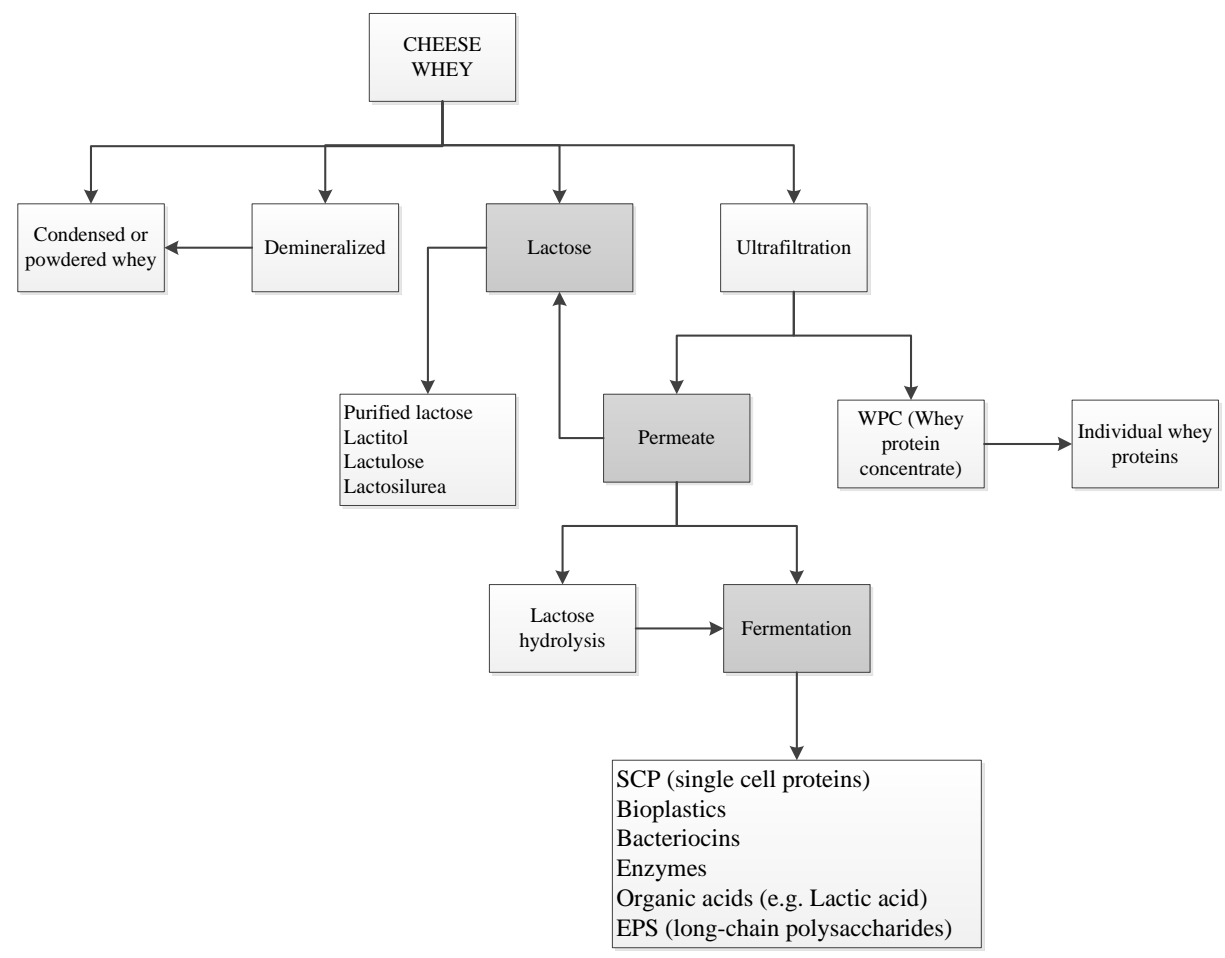

Figure 1. Scheme of current possibility of whey valorization. 


\section{Whey proteins}

Today, whey is a popular dietary protein supplement purported to provide antimicrobial activity, immune modulation, and to prevent cardiovascular disease and osteoporosis. In addition, whey has the ability to act as an antioxidant, antihypertensive, antitumoral, hypolipidemic, antiviral, antibacterial, and chelating agent [9].

Advances in processing technology, including ultrafiltration, microfiltration, reverse osmosis, and ion-exchange, have resulted in development of several different finished whey products: whey protein concentrates (WPC) containing between 50 - 85\% protein on a dry basis, whey protein isolate (WPI) containing between $90-98 \%$ protein and very small amounts of lactose and fat, reduced lactose whey, demineralized whey and hydrolyzed whey [10]. Each whey product varies in the amount of protein, carbohydrates, immunoglobulins, lactose, minerals, and fat in the finished product [9].

Nowadays whey ultrafiltration (UF) and diafiltration (DF) are standard operations in the dairy industry that allow protein recovery without significant loss of their functional properties and with a low salt content, making it suitable for human consumption $[11,12]$.

The recovery of proteins by UF and DF represents the first step in whey valorisation. UF has been used in the dairy industry to produce WPC, because this technology allows the selective concentration of the proteins in relation to the retention of protein and selective permeation of lactose, minerals, water and compounds of low molecular weight [10]. DF is used for the production of WPC with a high protein content and purification grade. WPC, which are obtained by whey UF and DF are available in great variety according to protein content and functional properties $[7,9]$.

Whey proteins have a high nutritional value, due to the high content of essential amino acids, especially sulfur-containing ones [13].They are high quality proteins with a protein efficiency ratio (PER) of 3.4, higher than casein (2.8) and similar to egg albumin [14].

Moreover whey proteins have functional properties (e.g. high solubility, water absorption, gelatinization and emulsifying capacities) essential in food application [15].

Thanks to the excellent nutritional and functional properties, commercial value of WPC is from 3 to 40 times greater than that of whey powder [1].

Moreover, the possibility of a different use of whey proteins is taken into account to obtain the so-called "functional foods". Individual whey proteins have their own unique nutritional, functional and biological characteristics that are unrealised in whey protein concentrates. WPC micro-, submicro- and nanocapsules have been applied in the encapsulation of bioactives of interest in the development of novel functional foods (e.g. the antioxidant $\beta$-carotene) [16].

The major components among whey proteins are $\beta$-lactoglobulin $(\beta$-LG), $\alpha$-lactalbumin $(\alpha$ LA), bovine serum albumin (BSA) and immunoglobulin (IG), representing 50\%, 20\%, 10\% and $10 \%$ of the whey fraction, respectively. All of these major proteins, except for BSA and 
IG, are synthesized by epithelial cells in the mammary gland. Besides these, whey contains also numerous minor proteins, called low abundance proteins, such as lactoferrin (LF), lactoperoxidase (LP), proteose peptone (PP), osteopontin (OPN), lisozyme (LZ), among others; LF and LP are the most abundant minor proteins $[17,18]$.

The concentration of whey proteins depends on the type of whey (acid or sweet), the source of milk (bovine, caprine or ovine), the time of the year, the type of feed, the stage of lactation, and the quality of processing. Whey proteins are globular molecules with a substantial content of $\alpha$-helix motifs, in which the acidic/basic and hydrophobic/hydrophilic amino acids are distributed in a fairly balanced way along their polypeptide chains [19]. Major characteristics of whey proteins are summarized in Table 1.

\begin{tabular}{ccccc}
\hline Protein & $\begin{array}{c}\text { Molecular mass } \\
(\mathbf{K g} / \mathbf{m o l})\end{array}$ & $\begin{array}{c}\text { Isoelectric } \\
\text { point }\end{array}$ & $\begin{array}{c}\text { Concentration } \\
\mathbf{( g / l )}\end{array}$ & $\begin{array}{c}\text { Number of amino } \\
\text { acids }\end{array}$ \\
\hline B-LG & 18 & 5.4 & 3.2 & 162 \\
\hline a-LA & 14 & 4.4 & 0.7 & 123 \\
\hline Immunoglobulin G & 150 & $5 \div 8$ & 0.4 & 582 \\
\hline BSA & 66 & 5.1 & 0.1 & 700 \\
\hline LF & 77 & 7.9 & 0.03 & 612 \\
\hline LP & 78 & 9.6 & & $*$ \\
\hline
\end{tabular}

*variable values

Table 1. Major characteristics of whey proteins $[20,18,21]$.

The three major forms in which whey protein products are available, such as concentrates (WPC), isolates (WPI), and hydrolysates (WPH), have limited acceptance by the food processing industry because of the lack of consistency in the gross composition and functionality. Whereas each whey protein has unique attributes for nutritional, biological and food ingredient applications; otherwise individual milk proteins exhibit better functionality than in their native protein mixtures [22,9].

As a matter of fact whey represents a rich mixture of proteins with wide-ranging chemical, physical and functional properties. These proteins play an important role in nutrition and, in a number of instances, also appear to have specific physiological actions, such as: ability to bind metals, functions related to the immune or digestive systems, source of essential amino acids also branched chain amino acids (leucine, isoleucine, and valine) which are thought to play a role as metabolic regulators in protein and glucose homoeostasis, involvement in lipid metabolism, etc. [23,24].

By this way these bioactive compounds are able to reduce disease risk and/or to prevent disease development and have been reported to have utility in many different applications ranging from effects on bone, muscle, blood, brain, pancreas, immune, cancer, infection, me- 
tabolism, wound healing, learning, and aging [25]. Moreover, these proteins, once partially digested, serve as a source of bioactive peptides with further physiological activities.

All of these biological and physiological activities offer to the food industry several opportunities; in particular they provide the basis for development of valuable whey protein-based food ingredients targeted to the functional food sector [26].

The term functional food was first introduced in Japan in 1980's: it refers to healthy food similar in appearance to conventional food, consumed as part of a usual diet, and claimed to have physiological benefits like health-promoting or disease-preventing properties beyond the basic function of supplying nutrients. Various definitions of functional food, proposed by authorities, academic bodies and industries, exist worldwide; the difficulty to give a unique definition depends on the fact that foods consumed perform some functions in one way or the other, in particular depending on the state of health of the consumer. Moreover various different terms, listed in Table 2, are sometimes linked or interchanged with the term functional foods $[13,27,28]$. Considering on one hand the ambiguity among these definitions and on the other the wide set of functions of whey proteins and related peptides, it is quite difficult to establish whether they fall within a definition or into another.

\begin{tabular}{ll}
\hline \multicolumn{1}{c}{ Terms } & \multicolumn{1}{c}{ Definition } \\
\hline Bioactive compounds: & $\begin{array}{l}\text { they are chemical compounds derived from a plant, animal, or marine source, that } \\
\text { exert the desired health/wellness benefit. }\end{array}$ \\
\hline Dietary supplements: & $\begin{array}{l}\text { they act as a supplement to the diet in which the active ingredient is added to the } \\
\text { food or it can be consumed in the form of pills, powders, or in liquid forms; they do } \\
\text { not replace the complete food or meal. }\end{array}$ \\
\hline Functional ingredients: & $\begin{array}{l}\text { they are preparations, fractions or extracts containing bioactive compounds of } \\
\text { varying purity, that are used as ingredients by manufacturers in the food. }\end{array}$ \\
\hline they are formulated to be administered under the supervision of a physician, for the \\
specific dietary management of a disease or condition for which distinctive nutritional \\
requirements are established.
\end{tabular}

Table 2. Different terms linked or interchanged with functional foods $[29,28]$. 


\subsection{Whey proteins separation}

Protein functions are related to their native structure, which depends on $\mathrm{pH}$, temperature, pressure and solvent effects. Changes in native structure affect functional properties, by this way in the last years there has been a great interest in developing efficient separation and purification processes that prevent denaturation and loss of biological activity. On the other hand fractionation can emphasize the functional and nutritional properties of the individual proteins [30,31].

Separation processes tend to exploit to the maximum extent different molecular masses, concentrations, and isoelectric points of whey proteins. The main available processes for commercial-scale production of whey protein fractions belong to four categories: selective precipitation, membrane filtration, selective adsorption, and selective elution [20].

A brief description and some examples for each separation category are after-presented.

- Selective precipitation involves adjusting the solution physical properties to promote insolubility. Proteins are typically least soluble at a $\mathrm{pH}$ near the isoelectric point ( $\mathrm{pI}$ ) and in low ionic strength solutions, and most likely to aggregate under these conditions. While $\beta$-LG precipitates rapidly and selectively at high temperature $\left(70-120{ }^{\circ} \mathrm{C}\right)$ and $\mathrm{pH}$ near neutral ( $\mathrm{pH} 8), \alpha$-LA precipitates and aggregates better at acidic $\mathrm{pH}(3.5-5.5)$ and moderate temperature $\left(50-65^{\circ} \mathrm{C}\right)$ with long reaction times, usually accompanied by the precipitation of bovine serum albumin, immunoglobulins and lactoferrin, while $\beta$-LG remain soluble [32,33].

- Membrane filtration is commonly used to make whey protein concentrate, a mixture of all the proteins in whey, with the aid of membranes with a 5,000 to $10,000 \mathrm{~g} / \mathrm{mol}$ molecular mass rating. As regard fractionation, traditionally it has been based solely on differences in molecular mass; by this way in the past fractionation was possible only for proteins with great differences in molecular mass (e.g. $\alpha$-lactalbumin vs. IGG) or for proteins with a great combined difference in charge and size. Nowadays it is possible to achieve separation also when proteins have little or no difference in molecular mass together thanks to a careful adjustment of the solution $\mathrm{pH}$ and ionic strength [34,35]. The electrostatic rejection by the membrane, due to their slight residual charge can be enhanced or reduced by adjusting the solution $\mathrm{pH}$. Furthermore separation is enhanced by operating near the $\mathrm{pI}$ of the smaller protein and far from the $\mathrm{pI}$ of the larger protein to maximize the difference in effective hydrodynamic size: this because the effective diameter of a protein increases with decreasing ionic strength. Low salt concentrations (1-20 mmol/L) increase electrostatic and steric rejection by the membrane: by this way a multi-step adjustment of the $\mathrm{pH}$ and ionic strength of the whey may allow fractionation of proteins using a sequence of membrane separation processes [20]. As an example reference [36] is reported; in this experimental study, the effect of working $\mathrm{pH}$ was evaluated, employing a $300 \mathrm{kDa}$ tubular ceramic membrane in a continuous diafiltration mode, by measuring the flux-time profiles and the retentate and permeate yields of $\alpha-\mathrm{LA}, \beta-\mathrm{LG}, \mathrm{BSA}, \operatorname{IgG}$ and LF. It was found that a $300 \mathrm{kDa}$ membrane could be employed to fractionate the original array of whey proteins in two parts: $\alpha$-LA and $\beta$-LG in the permeate and BSA, IGG and LF in the reten- 
tate. As a matter of fact important protein yields for $\alpha$-LA and $\beta$-LG were obtained in the permeate (except for $\mathrm{pH} 4$ and 5), while for the rest of the proteins studied, there was no significant diffusion through the membrane.

- In selective adsorption, a single purified protein is produced in conjunction with a treated whey solution depleted in that protein; the cost of manufacture must be borne by the income generated from that single purified protein product and the depleted whey solution $[20,36]$. There are many examples of selective adsorption processes for whey proteins: the immobilized hexapeptide ligand affinity resin or immobilized phenyl groups were used for $\alpha$-LA, while for $\beta$-LG immobilized retinal or ceramic hydroxyapatite chromatography with sodium fluoride as a displacer were applied [37-40].

- In selective elution all the proteins in a mixture are trapped simultaneously onto the adsorbent, rinsed free of contaminants, and then eluted one by-one to obtain different purified proteins. The process uses an adsorbent and buffers that are inexpensive and foodgrade, and it is operated at a high flow rate. Further on the cost of manufacture is spread among many purified protein products with the possibility to manufacture different products simply by using different elution buffers; by this way it is considered an attractive alternative to selective adsorption [41]. Differently from precipitation and membrane separation processes, which are volume-dependent separation methods, selective adsorption and selective elution processes are less volume dependent because adsorbent capacity depends mostly on the mass of protein recovered, not the volume of liquid processed [42]. Various studies about the development of ion exchange or affinity chromatography processes to separate whey proteins exist; referring as a case in point [43] various superparamagnetic anion-exchangers and their use together with cation-exchangers in the fractionation of bovine whey proteins (LF, LP, IG, and $\beta$-LG) were studied. While in reference [41] all the positively charged proteins in whey were bound simultaneously to a cation exchange column, rinsed free of contaminants and then eluted selectively to produce different fractions: with a single piece of equipment they were able to manufacture WPI, or $\alpha$-LA and WPI depleted in $\alpha$-LA or LF and LP only.

\subsection{Biological properties of individual whey proteins}

\subsection{1. $\beta$-lactoglobulin ( $\beta-L G)$}

$\beta$-lactoglobulin, a member of the lipocalins family, is the major whey protein of ruminant species, $58 \%(\mathrm{w} / \mathrm{w})$. It is present in many mammalian species but absent in human milk. Genetic variants of a single gene, of which $\beta$-LG A is the most common, have been widely reported particularly in the cow [44,21].

The lipocalins family presents various kind of features, most of which involve some ligandbinding functions; these last must be the physiological reason for the significant quantities of $\beta$-LG found in milk (the domestic cow produces 2 to $3 \mathrm{~g} \mathrm{~L}^{-1}$ ) [45].

In isolated form, despite its globular nature, it exhibits a low solubility and a low ionic strength. It contains normally 162 aminoacidic residues and has a molecular weight of 
$18,362 \mathrm{~g} / \mathrm{mol}$. The secondary structure of this protein comprises nine strands of $\beta$ structure, a short $\alpha$ helix segment and three helicoidal turns [46].

Its quaternary structure depends on the medium $\mathrm{pH}$ : at $\mathrm{pH}$ values between 7 and 5.2 it is a stable dimer (molecular weight of 36,700 kDa); at $\mathrm{pH}$ values between 5.2 and 3.5, an octamer (molecular weight of ca. 140,000 kDa); and below pH 3.0 and above 8.0, a monomer, with two-cysteine residues per monomer [47].

\subsubsection{1. $\beta$-LG biological functions}

The endogenous function of $\beta$-LG is not clear, but it is known that it is a source of amino acids. Indeed $\beta-\mathrm{LG}$, over-expressed in the lactating mammary gland of many species, is primarily an important source of amino acids for the offspring of those animals that produce it [45]. The amino acid content fuels muscle growth and it is a source rich in cysteine, which is important for the synthesis of glutathione [13].

It participates in the digestion of milk lipids in the neonate: $\beta$-LG binds to free fatty acids as they are released by pregastric lipases, by this way the digestion of milk fat is facilitated [48].

$\beta$-LG is the major allergen in cow's milk, responsible for causing milk allergy [25]. It was evidenced that milk's major allergen can be rendered non-allergenic and it can also be modified or administered inhibiting rather than stimulating the allergic process. $\beta$-LG has been conjugated with acidic oligosaccharides to reduce its antigenicity. Immunization of mice with the conjugates leads to a reduced $\mathrm{T}$ cell response, predominantly Th1-mediated, suggesting that the conjugates may have utility in preventing Th2-mediated allergy [49]. Oral administration of recombinant Lactococcus lactis expressing bovine $\beta$-LG induces a specific Th1 response, suggesting that probiotics expressing $\beta$-LG could be useful in the management of food allergy [50]. Intranasal co-administration of live lactococci expressing IL-12 and $\beta$-LG produces a protective Th1 response that inhibites allergic airway disease in mice [51]. Acidic $\beta$-LG-derived peptides hydrolyzed with Lactobacillus paracasei peptidases represse lymphocyte stimulation, upregulate IL-10 production, and downregulate IFN- $\gamma$ and IL-4 secretion [52].

$\beta$-LG structure comprise a ligand-binding site. The ligands that bind to $\beta$-LG tend to be hydrophobic and include long-chain fatty acids, triglyceride, retinoids, cholesterol and, more weakly, hydrocarbon molecules [53].

$\beta$-LG can also be a source of peptides with different functions:

- Lactokinins, Tyr-Leu (f102-103) and Ala-Leu-Pro-Met-His-Ile-Arg (f142-148), are inhibitors of angiotensin-I-converting enzyme (ACE) and represent potential nutraceuticals/functional food ingredients for the prevention and/or treatment of high blood pressure [54].

- $\beta$-lactorphin (f102-105) has ACE-inhibitory activity, improved vascular relaxation in spontaneously hypertensive rats, and it is an opioid receptor agonist suggesting that it can modulate absorption processes in the intestinal tract [55].

- Beta-lactotensin, His-Ile-Arg-Leu (f146 -149), is an ileum-contracting peptide, which exhibits hypertensive activity. It is a natural ligand for neurotensin NT2 receptors, has an 
anti-stress effect, promotes the abolition of fear memory, reduces sensitivity to painful stimuli, and consolidates memory. It is able to reduce blood cholesterol levels, but only when given parenterally, and not orally [56-58].

\subsection{2. $\alpha$-lactalbumin ( $\alpha-L A)$}

$\alpha$-lactalbumin is one of the most studied proteins: it is an important component of milk and it contributes significantly to its physical, biological and nutritional characteristics [59]. It is biosynthesized in the mammary gland during lactogenesis, and participates actively in the synthesis of lactose [60].

In human whey, $\alpha$-LA is a major protein $(1.7 \mathrm{mg} / \mathrm{mL})$; however, in bovine whey it is ranked second with respect to protein content after $\beta$-LG. The bovine protein is characterized by its relatively low molecular mass $(14.2 \mathrm{kDa})$ and its acidity (isoelectric point of 4.8$)$; $\alpha$-LA possesses a high mineral content and a balanced amino acid composition indeed its sequence is composed of 123 amino acids, that includes four residues of tryptophan and a high proportion of essential amino acids, Cys, Ile, Leu, Lys [61,62].

The structure of bovine $\alpha$-LA is highly stabilized by four disulphide bonds and by the association of $\mathrm{Ca}^{2+}$ at the binding loop that joins together two domains of the protein: a large $\alpha$ helical and a small $\beta$-sheet domains $[63,64]$.

In addition to $\mathrm{Ca}^{2+}$ ion, $\alpha$-LA is able to bind several other cations such as $\mathrm{Mg}^{2+}, \mathrm{Mn}^{2+}, \mathrm{Na}^{+}$and $\mathrm{K}^{+}$and also contains various $\mathrm{Zn}^{2+}$ binding sites [65]. Nevertheless, only the binding of $\mathrm{Ca}^{2+}$ ion is fundamental for the maintenance of the native conformation of the protein $[66,67]$.

\subsubsection{1. $\alpha$-LA biological functions}

$\alpha$-LA and its biological and functional peptides are characterized by potential health benefits; as regard of that there is a growing scientific interest in the context of health-promoting functional foods. In particular, $\alpha$-LA and $\alpha$-LA-peptides can be used as supplements of essential amino acids in food to improve/maintain the immune system, to reduce the stress, for opioid activity, antihypertensive action, regulation of cell growth, immunomodulation etc. [68].

$\alpha$-LA is cytotoxic and this property can be exploited for therapeutic uses. $\alpha$-LA has protective properties against mucosal injury[69,70].

$\alpha$-LA is particularly rich in essential amino acids. It has a high content of lysine and cysteine and a particularly high content of tryptophan (5.9\% of the total amino acid content) [61].

The high content in tryptophane makes $\alpha$-LA a nutraceutical; in particular it may help improve mood, sleep, and cognitive performance [71,72]. On the other hand the content of cysteine is valuable in boosting the immune system and promoting wound healing. As a general consideration, thanks to the high content in essential amino acids, $\alpha$-LA is an invaluable supplement for infant formulas [68].

The protein may possess bactericidal or antitumor activity. The active form of the protein is called "human $\alpha$-LA made lethal to tumor cells" (HAMLET), a complex formed by which 
induces apoptosis in tumor cells but spares mature cells and has received much attention due to its potential use as a new therapeutic agent against tumor cells [73].

The digestion of $\alpha$-LA with trypsin and chymotrypsin creates some polypeptides with bactericidal properties, mostly against Gram-positive bacteria and a weak bactericidal activity against Gram-negative strains. The peptide $\alpha$-lactorphin behaves like opioid receptor agonists $[74,75]$.

$\alpha$-LA has a marked suppressive effect against the increased release of proinflammatory cytokines and tumor necrosis factor- $\alpha$, from the D-galactosamine induced liver injury rat model or ischemia/reperfusion induced intestinal injury rat model [76]. Two synthetic peptides corresponding to the sequences f50-51 (Tyr-Gly) and f18-20 (Tyr-Gly-Gly) of $\alpha$-LA also enhance both the in vitro proliferation and protein synthesis of concanavalin A-stimulated human peripheral blood lymphocytes [77].

\subsubsection{Immunoglobulins (IG)}

Immunoglobulins constitute a complex group of elements produced by B-lymphocytes and their concentration in whey is $0.7 \mathrm{~g} / \mathrm{l}$. IG are divided into three basic classes: IGG, IGA and IGM. IGG is often sub-divided into two subclasses, IGG1 and IGG2. IGG represents up to $80 \%(\mathrm{w} / \mathrm{w})$ of all IG in milk or whey. Qualitatively the family of IG found in bovine whey and colostrum include IGA, secretory IGA, IGG1, IGG2, IGG fragments, IGM, IGE, J-chain or component, and free secretor component $[78,21]$.

IG make a significant contribution to the whey protein content and they exert an important immunological function (especially in colostrum). IG are subject to postnatal transfer via colostrum because the placenta does not permit passage of macromolecules. These proteins are present in the serum and physiological fluids of all mammals; some of them attach to surfaces, where they behave as receptors, whereas others function as antibodies, which are released in the blood and lymph [79].

In terms of quaternary structure, IG are either monomers or polymers of a four-chain molecule, consisting of two light polypeptide chains (with a molecular weight in the range 25,000 $\mathrm{kDa}$ ) and two heavy chains (with molecular weight of 50,000-70,000 kDa) [80].

\subsubsection{IG biological functions}

Milk immunoglobulins normally provide passive immunity for the neonate, but they are also potentially powerful agents that could be incorporated into diets to remove toxic, or undesirable dietary factors. As an example, naturally occurring antibody in milk can be extracted which binds to cholesterol in the human digestive tract and prevents its absorption into the bloodstream. This anti-cholesterol antibody can be a useful food supplement for the functional food market [25].

Concerning IG antimicrobial and antiviral properties it is known that concentration of colostrum whey antibodies against a particular pathogen can be raised by immunising cows with the pathogen or its antigens. Antibody concentrates derived from immune milk collected 
from cows immunised with inactivated human rotavirus possess preventive/treatment features in enteric disease caused by said viruses in therapeutics of child infections [81]. The hyperimmune whey that results can potentially provide prophylactic protection against various infectious gut microbes including rotavirus and Helicobacter pylori [82]. Infant gastritis originated by $H$. pylori is well fought via a diet including immune milk containing specific anti-H. pylori antibodies [83]. There is also evidence of protection via bovine antibodies against dental caries caused by cariogenic streptococci [84].

IG can also act in the immune system modulation; they are recognised to provide protection against diseases in the newborn through passive immunity. Systemic immunisation of pregnant cows increases the levels of antibodies against immunising bacteria, and also reduces susceptibility to disease [85]. Vaccination of pregnant cows originates colostrum characterized by high concentrations of specific antibodies against the antigens of the vaccine used [86].

Other methabolic features of IG are also known. Immune milk is suggested to lower blood pressure. In reference [87] a clinical-trial study regard the effects on reduction of cholesterol and blood pressure of immune milk, produced by dairy cows previously hyper-immunised with a multivalent bacterial vaccine, was described. The involved human hypercholesterolemic subjects consumed $90 \mathrm{~g}$ of immune milk daily: this was a useful adjunct in the dietary management of hypercholesterolemia.

\subsubsection{Bovine Serum Albumin (BSA)}

Bovine serum albumin represents the $5 \%$ of the whey proteins and its concentration in whey is about $0.4 \mathrm{~g} / \mathrm{l}$. It appears in milk following passive leakage from the blood stream indeed it is not synthesized in the mammary gland $[21,25]$. The most outstanding property of BSA is its ability to bind reversibly various ligands; in particular it is the principal carrier of fatty acids [88].

It contains 582 amino acid residues, which lead to a molecular weight of $66,267 \mathrm{kDa}$; it also possesses 17 intermolecular disulphide bridges and one thiol group at residue 34 [89]. BSA molecule is heart-shaped; it consists of three homologous $\alpha$-helical domains and each domain contains two sub-domains that share common structural motifs [88].

Thanks to its size and higher levels of structure, BSA can bind to free fatty acids and other lipids, as well as flavor compounds, this feature is severely injured upon denaturation [90].

Its heat-induced gelation at $\mathrm{pH} 6.5$ is initiated by an intermolecular thiol-disulphide interchange, similar to what happens with $\beta$-LG [78].

\subsubsection{BSA biological functions}

BSA has the ability to inhibit tumor growth thanks to the modulation of activities of the autocrine growth regulatory factors; this was evidenced by in vitro incubation with human breast cancer cell line MCF-7 [91]. In relation to this activity [92] the delivery system MTOBSA-NS (mitoxantrone nanoparticles loaded with bovine serum albumin) was studied; human MCF-7 breast cancer in nude mice and animal model of P388 lymphnode metastases in 
Kunming mice were applied to investigate the therapeutic efficiency. The inhibition rate of the nanospheres against breast cancer was high and lymphnode metastases were efficiently inhibited.

BSA is able to bind fatty acids stored in the human body as fat; this allows BSA to participate in synthesis of lipids [93]. BSA has also antioxidant activities; in vitro it is able to protect lipids against phenolic-induced oxidation [94]. BSA is also a source of essential amino acids, whose therapeutic potential is largely unexplored.

Biological functions of some BSA-derived peptides have also been examined. The peptide serorphin (Tyr-Gly-Phe-Gln-Asn-Ala) (f399-404) has opioid agonist activity, while the peptide albutensin A (Ala-Leu-Lys-Ala-Trp-Ser-Val-Ala-Arg) (f208 -216) is an ACE inhibitor and is reported to have ileum contracting and relaxing activities [54].

\subsubsection{Lactoferrin (LF)}

Lactoferrin together with lactoperoxidase is one of the minor whey proteins. It belongs to the transferrin family which is composed by proteins capable of binding and transferring $\mathrm{Fe}^{3+}$ ions. LF is a glycoprotein characterized by a molecular weight of $80,000 \mathrm{kDa}$. It is synthesized by glandular epithelial cells and mature neutrophils, and can be found in milk, saliva, tears, nasal and intestinal secretions, pancreatic juice, seminal fluid, and in secondary granules of neutrophils. Bovine milk contains between 0.02 and $0.35 \mathrm{mg} / \mathrm{ml}$ of LF, depending on the period of lactation $[25,95]$.

LF is a bilobal protein that contains two homologous metal-binding sites with high affinities for ferric iron. The iron-binding sites are situated in the inter-domain clefts. The requirement for an anion, bound synergistically with the Fe ion is a unique feature of LF. Iron release can occur at low $\mathrm{pH}$ and is associated with a large-scale conformational change in which the two domains that enclose each iron-binding site move wide apart [96].

LF possess a wide range of biological functions, many of which are not connected with its iron binding ability; it is the most valuable biomedical protein present in whey due to the various therapeutic properties it exhibits $[97,25]$.

\subsubsection{LF biological functions}

LF has quite important role in iron metabolism. It may contribute to local iron accumulation at sites of inflammation and it has been known to be responsible for hypoferraemia through binding free iron and shuttling it back to macrophages [98,97]. LF might also have a control function in situations when increased amounts of iron are released from its depots [99]. Further on LF seems to affect intestinal iron absorption in infants depending on the organisms need for iron [100].

LF is a part of the innate immune system and it also takes part in specific immune reactions; it represents one of the first defense systems against microbial agents [101,95].

LF can have a bacteriostatic effect thanks to its ability to bind free iron, essential for the growth of bacteria (e.g. E. coli). LF, as an iron donor, supports the growth of Lactobacillus sp. 
or Bifidobacterium sp., characterized by a lower iron demands and generally considered as beneficial [102,103]. LF owns also a bactericidal effect, which is not iron-dependent, against Gram-negative and Gram-positive bacteria. In the first case there is the disruption in the cell wall because the microorganisms have the receptors for the N-terminal region of LF; while for Gram-positives, changes in the permeability of the membrane occurs mediated by electrostatic interactions between the lipid layer and LF surface [104,105]. LF may contribute to defense against the invasion of facultative intracellular bacteria such as: E. coli HB101, Yersinia enterocolica, Y. pseudotuberculosis, Listeria monocytogenes, Streptococcus pyogenes, and Staphylococcus aureus. LF binds both target cell membrane glycoaminoglycans and bacterial invasins. The proteolytic activity of LF inhibits the growth of Shigella flexneri and E.coli through degrading proteins necessary for colonization $[105,106]$.

The main contribution to antiviral defense of LF consists in its binding to glycosaminoglycans of cell membrane: viruses (Herpes simplex virus, cytomegaloviruses, human immunodeficiency virus) cannot enter cells and infection is stopped at an early stage [106]. LF is also capable of binding certain DNA and RNA viruses [107].

LF may support the proliferation, differentiation, and activation of immune system cells and strengthen the immune response; LF also acts as an anti-inflammatory factor. Thanks to its antimicrobial activity and capability of binding components of bacterial cell walls or their receptors, LF may prevent the development of inflammation and subsequent tissue damage caused by the release of pro-inflammatory cytokines and reactive oxygen species [101].

As regard the influence of LF on tumor growth, it is known that it is able to halt the growth of human mammary gland carcinoma cells between the G1 and S stage; this effect may be ascribed to the altered expression or activity of regulatory proteins [108]. The lactoferrin-dependent, cytokine-mediated stimulation of activity of NK cells and lymphocytes CD4+ and $\mathrm{CD} 8+$, represents an important factor in defense against tumor growth: after the oral administration of lactoferrin the number of these cells increases [109]. Even if the exact mechanism has to be discovered completely, it seems that LF-mediated inhibition of tumor growth might be related to apoptosis of these cells induced by the activation of the Fas signaling pathway [110].

LF is also able to act as a growth factor activator; it can have effect on small intestine epithelial cells and endometrium stroma cells [111]. It has also been identified as a transcription factor [112].

LF contributes to the stabilization of the osseous tissue; it may affect bone cells through the inhibition of osteolytic cytokines whose levels rise during inflammation. LF is a potent anabolic factor affecting osteocytes; it stimulates osteoblast proliferation, enhances thymidine incorporation into osteocytes, and reduces apoptosis of osteoblasts. By this way LF might be potentially useful in the treatment of diseases such as osteoporosis [113].

\subsubsection{Lactoperoxidase ( $L P)$}

Lactoperoxidase is member of the family of mammalian peroxidases. It is present in a variety of animal secretions (e.g. tears, saliva and milk), it is one of the most abundant enzymes 
in plain milk and represents $1 \%(\mathrm{w} / \mathrm{w})$ of the total protein pool in whey; its concentration in whey corresponds to $0.03 \mathrm{~g} / 1$ [114].

LP consists of a single polypeptide chain containing 612 amino acid residues and its molecular mass is about $80 \mathrm{kDa}$. It contains 15 half-cystine residues and carbohydrate moieties comprise about $10 \%$ of the weight of the molecule [115].

The complete LP system (i.e. enzyme plus substrate) was originally characterized in milk [116]; its activity depends on many factors (e.g. animal species, breed and lactation cycle). Other members of that group of oxidoreductases include myeloperoxidase (present in neutrophils and monocytes), eosinophil peroxidase and thyroid peroxidase; they are characterized by a close evolutionary relationship [21].

\subsubsection{LP biological functions}

LP is characterized by the antimicrobial activity related to the LP system, formed by LP, thiocyanate anion, and hydrogen peroxide, which is active only in the presence of all these three components: LP catalyses the oxidation of thiocyanate by $\mathrm{H}_{2} \mathrm{O}_{2}$ and generates intermediate products with a broad spectrum of antimicrobial effects against bacteria, fungi and viruses. The LP system is naturally occurring in milk and saliva and has been used in foods, cosmetics and in clinical applications because of its safety and broad spectrum of action; in particular it is fundamental in the dairy industry for the preservation of raw and pasteurized cheese, and yogurt $[117,118]$.

The thiocyanate anion is significantly present in saliva, milk and airway secretions. The amount of the anion in cow's milk ranges from 0.1 to $15 \mathrm{mg} / \mathrm{kg}$ and its concentration varies according to animal species, breed, lactation cycle, season and composition of feed [114,21].

Hydrogen peroxide is not normally detected in raw milk. It may be generated endogenously by polymorphonuclear leucocytes or under aerobic conditions by many lactobacilli, lactococci, and streptococci. $\mathrm{H}_{2} \mathrm{O}_{2}$ is normally present to very small levels because its content is rapidly reduced by catalases and peroxidases that are adventitious in milk [119-121].

The major intermediary oxidation product, at physiological $\mathrm{pH}$, is hypothiocyanate; it mediates bacterial killing, as it is cell-permeable, and can inhibit glycolysis, as well as (NADH)/ (NADPH)-dependent reactions in bacteria. It is bactericidal for enteric pathogens including multiple antibiotic resistant strains of E. coli. Other reaction products of the LP system, such as cyanosulphurous acid and cyanosulphuric acid, are able to oxidise sulphidrile groups of bacterial proteins $[114,21]$.

The LP system inhibit Gram-negative, catalase positive organisms, such as pseudomonas, coliforms, salmonellae and shigellae; these microorganisms can also be killed if $\mathrm{H}_{2} \mathrm{O}_{2}$ is supplied exogenously. Gram-positive, catalase negative bacteria, such as streptococci and lactobacilli are generally inhibited but not killed by the LP system [122,121].

The LP system exerts both bacteriostatic and bactericidal activities against strains of Salmonella typhimurium, S. aureus, and L. monocytogenes; the system is bactericidal against Campylobacter jejuni, Brucella melitensis. As regard Bacillus cereus, Streptococcus mutans, Streptococcus 
sanguis, Streptococcus mitis, and Streptococcus salivarius the LP system has an inhibitory effect [123-127,121].

The antifungal activity of the LP system with glucose oxidase as $\mathrm{H}_{2} \mathrm{O}_{2}$ source has been reported against Rhodutorula rubra, Saccharomyces cerevisiae, Mucor rouxii, Aspergillus niger, and Byssochlamys fulva in salt solution and in apple juice. The LP-thiocyanate- $\mathrm{H}_{2} \mathrm{O}_{2}$ system was found to inhibit the growth and proliferation of many fungal species (e.g. Aspergillus flavus, Trichoderma spp.); the same system showed also antifungal activity against Alternaria spp., Penicillium chrysogenum and Claviceps spp. [128,121].

Finally, as regard the antiviral properties of the LP system, the ability to kill both poliovirus and vaccina virus with halides $\left(\mathrm{I}^{-}, \mathrm{Br}^{-}\right)$as electron donors has been reported [129]. In references $[130,131]$ the $\mathrm{LP}-\mathrm{H}_{2} \mathrm{O}_{2}$-halide system virucidal activity against HIV-1 was reported.

\section{Whey fermentation products}

During last 50 years, cheese whey was used in different bioconversions; for examples the microbial biomass production for animal feed supplement [132], biogas production using anaerobic methanogenic bacteria [14], bioethanol production by Kluyveromyces marxianus $[133,134]$ or recombinant Saccharomyces cells $[135,136]$, hydrolized lactose solution in sweeteners and dietary supplements production [14].

Therefore, at present, it can be very interesting and promising to consider again the possibility to use cheese whey and, particularly, glycidic component because of new demands, as bioplastic synthesis (poly-hydroxyalkanoates -PHA- and polylactate acid -PLA-), antimicrobial peptides (bacteriocins), enzymes and esopolisaccharides (EPS).

Just below, there are the information regarding the fermentative production of the molecules and macromolecules previously mentioned.

\subsection{Polyhydroxyalcanoate}

Polyhydroxyalkanoates (PHA) are aerobic bacteria synthesized macromolecules (polyesters); they are carbon and energy reserve, accumulated as intracellular granules. These microbial compounds play the same role as glycogen and starch in animal and plant cells, respectively [137].

Among biodegradable plastics, PHA are very interesting polymers because of their chemical, physical and mechanical properties comparable to petroleum-derived plastics (polyethylene and polypropylene); otherwise, PHA are different for their complete biodegradability, UV-resistence, oxygen-impermeability (fundamental property for food packaging) and biocompatibility (essential property for medical and surgery applications) [138,139]. 
Under unbalanced growth conditions (limitation of essential nutrients, e.g., nitrogen, phosphate, or oxygen), several microorganisms redirect the acetyl-CoA flux from biomass formation towards accumulation of PHA [140,141].

At present, these biopolymers are synthesized in pure cultures, using synthetic pure substrates (as monosaccharides and organic acids), in macronutrient limiting conditions $(\mathrm{N}, \mathrm{O}$, $\mathrm{P})$. Because of substrate weights on whole process cost at $40 \%$, it becomes necessary to search alternative cheaply available source materials for PHA production, as food by-products (e.g. cheese whey).

In the last two decades, a broad number of studies were related to the production of PHA from milk whey permeate using pure cultures of wild type microorganisms or recombinant ones. In several of these works, whey lactose was hydrolyzed by lactase: poly-(3HB-3HV) was produced with Ralstonia eutropha DSM545 on whey permeate and inverted sugars [142], poly-3-(hydroxybutyrate-co-hydroxyvalerate) was produced by P. hydrogenovora with hydrolyzed whey permeate and sodium valerate [143].

In [141] Hydrogenophaga pseudoflava DSM1034 was reported as unique example of wild type microorganism able to synthesize PHA directly from lactose, three possible routes from whey lactose to PHA have been suggested: direct conversion of lactose to PHA, hydrolysis of lactose (chemically or enzimatically) and conversion of glucose and galactose to PHA, lactose fermentation to lactic acid and then conversion of lactic acid to PHA. In reference [144] a recombinant E. coli strain GCSC 6576 and whey powder was used in a pH-stat fed-batch fermentation. After $47 \mathrm{~h}$ of fermentation, it was obtained a dry cell weight and $\mathrm{P}(3 \mathrm{HB})$ concentration of $109 \mathrm{~g} \mathrm{~L}^{-1}$ and $50 \mathrm{~g} \mathrm{~L}^{-1}$, respectively. Further, with the same organism and using $\mathrm{pH}$-stat fed-batch culture and concentrated whey solution containing $210 \mathrm{~g} \mathrm{~L}^{-1}$ lactose as nutrient feed, a dry cell weight of $87 \mathrm{~g} \mathrm{~L}^{-1}$ and $\mathrm{P}(3 \mathrm{HB})$ concentration of $69 \mathrm{~g} \mathrm{~L}^{-1}$ containing $87 \%$ dcw $\mathrm{P}(3 \mathrm{HB})$ was achieved. Using the recombinant E. coli strain $(\mathrm{K} 24 \mathrm{~K})$, the authors successfully produced $70.1 \mathrm{~g} \mathrm{~L}^{-1}$ biomass containing $51.1 \mathrm{~g} \mathrm{~L}^{-1} \mathrm{P}(3 \mathrm{HB})$ in a $\mathrm{pH}$ controlled fed-batch fermentation at $\mathrm{pH} 7.20$ with whey and corn steep liquor as carbon and nitrogen sources, respectively[145]. Previously, PHB production by Methylobacterium sp. ZP24 on lactose and whey with similar values of biomass polymer content was described [146].

Poly- $\beta$-hydroxybutyrate production was also described in lactic acid bacteria belonging to Lactococcus, Lactobacillus, Pediococcus and Streptococcus genera [147].

Lactic acid producing bacteria such as Lactobacillus lactis [148], Propionibacterium [149], L. delbrueckii [150-152] and C. necator have been also used in a co-culture fermentation system: LAB converted sugars into lactic acid which was later taken up by $C$. necator to produce PHAs. Generally, it has been demonstrated that co-culture fermentations resulted in increased yield, improved control of product qualities. A further advantage in the application of co-cultures is the possibility of utilizing secondary products (e.g. whey) cheaper than glucose as substrates for production of PHAs [153]. Bacteria that have a "generally recognised as safe" (GRAS) status for PHA-production such as lactic acid bacteria and bacilli belonging to probiotic species $[147,154]$ might constitute an added value to these biotechnological processes [155]. 


\subsection{Lactic acid}

Acetic, propionic, lactic, lactobionic, citric, gluconic and itaconic acids can be obtained from lactose/whey fermentation. Among organic acids that find applications in specialty chemicals, lactic acid is the most important from an economical point of view [156].

Lactic acid is used in food and chemical industries (pharmaceutical products, textiles, leather), primarily as a preservative and as acidulant [157-159]. Also it has applications as a biodegradable plastic component (polylactide, polymers, polyhydroxybutyrate) [159]. Notably, the industrial demand for lactic acid (LA) has been increasing considerably in recent years, owing to the promising applications of its polymer, the polylactic acid (PLA), as an environment-friendly alternative to plastics derived from petrochemicals [160].

Polylactic acid (PLA) is a biodegradable polyester made by condensation of lactic acid (LA) monomers [161]. It can be worked with conventional facilities and techniques to produce implant devices and internal sutures [162]. Due to its low toxicity, it is classified as GRAS and can be also used in food packaging [161,163], which is one of the widest fields of plastics market. PLA is completely biodegradable under compostable conditions: however, if disposed in landfills, it will last in the environment for years, likewise oil-based plastics [164].

Cheese whey effluents have been used in fermentation processes to produce lactic acid $[165-168,158,169,159]$. Microorganisms used in lactic acid production are Lactobacillus casei [166,157,158,169], Lactobacillus helveticus [170-172,168,156,159]; Lactobacillus acidophilus [167]; Lactobacillus delbrueckii [165,167,168]; Lactobacillus salivarius [169]; Lactococcus lactis [158]. Streptococcus thermophilus [167]; K. marxianus [168]; Leuconostoc and Pediococcus [4].

Among different lactobacilli species employed in lactic acid production, L. helveticus is the generally preferred organism, it is a homolactic LAB that produces LA in racemic mixture (DL) [173]. L. helveticus showed enhanced lactose utilisation and lactic acid production at $42^{\circ} \mathrm{C}$ and $\mathrm{pH} 5.8$ [159].

Currently, a high fraction of generated CW is managed by membrane processes, mainly, ultrafiltration. The obtained permeate has a low protein content and an elevated lactose and mineral salts concentration, both aspects are advantageous in lactic acid fermentation. As a consequence, several works have been carried out aimed at obtaining lactic acid after ultrafiltration of CW $[171,157,172,169]$. Highest lactic acid production rate was obtained with $L$. helveticus cultivated in whey permeate, with corn steep liquor (CSL) as the nitrogen source [174]. Lactic acid productivity of $9.7 \mathrm{~g} / \mathrm{L} / \mathrm{h}$ using L. helveticus strain milano has been obtained in continuous fermentation of whey-yeast extract permeate medium [173,175]. In a work with L. salivarum YE supplementation was replaced by in situ treatment of fermentation medium with proteolytic microorganisms [169].

However, lactic acid production from cheese whey or its permeate obtained without nutrients supplementation $[165,168,159,169$,$] is of limited application to industrial scale be-$ cause of the low productivity, nutrients supplementation is a key factor limiting the process efficiency. 
Some studies report the use of mixed cultures in lactic acid production with synergistic effects $[168,158]$. Other research groups tried to improve LA production using rE.coli harbouring an inducible expression plasmid containing D-lactate dehydrogenase encoding gene of Lactobacillus plantarum [176] or using metabolic engineering of LAB, fungal or yeast systems $[177,178,179]$, but all of these strategies, if compared with the use of mixed cultures, involve higher costs due to genetic engineering studies and the need of sterilization.

LAB have been immobilised by several methods on different supports (calcium alginate, k-carragenane, agar and polyacrylamide gels) [4] and the immobilised systems have been investigated for lactic acid production from whey. A two-stage process was used for continuous fermentation of whey permeate medium with L. helveticus immobilised in k-carrageenan/ locust bean gum, which resulted in high lactic acid productivity $\left(19-22 \mathrm{~g} \mathrm{~L}^{-1} \mathrm{~h}^{-1}\right)$ [172].

In [4] L. casei was immobilized in Ca pectate gel. A high lactose conversion (94.37\%) to lactic acid (32.95 $\left.\mathrm{g} \mathrm{L}^{-1}\right)$ was achieved and the cell system was found highly stable, no decrease in lactose conversion to lactic acid was observed up to 16 batches.

\subsection{Exopolysaccharides}

Exopolysaccharides (EPS) are long-chain polysaccharides $\left(4^{*} 10^{4}-6^{*} 10^{6} \mathrm{Da}\right)$. They are produced by bacteria and microalghe and can be divided in homopolysaccharides (Homo-EPS) and heteropolysaccharides (Hetero-EPS) [180]. Homo-EPS consist of either D-glucose (glucans) or D-fructose (fructans) residues, with different types of linkage and branching degree. Hetero-EPS are constructed from multiple copies of an oligosaccharide and show little structural similarity to one another: glucose, galactose, xylose, mannose, arabinose and rhamnose are the most represented sugars but also amino-sugars and polyols can be occasionally present as well as glucuronic acid. They are often highly branched with different binding types [181].

The physiological role of EPS is related to microbial cell protection from toxic compounds, phagocytosis, antibiotics effect and osmotic stress [182]. In the last years, their prebiotic role was identified and described $[183,184]$. In addition to role as food additives and prebiotics, LAB synthesized EPS have been implicated as anti-tumor agent, immuno-stimulator and blood cholesterol lowering agent [185,184].

On the basis of their rheological properties, EPS are applied as stabilizers and emulsifiers in food industry, particularly for yogurt, fermented milk and mozzarella production [186,187]. EPS used in food industry must be considered additives and, consequently, must ensure safety qualification. EPS synthesize by LAB, generally used in food production, possess this safety characteristics [184]. The GRAS and probiotic status of some lactobacilli give to them more preference for consumable EPS production. Main drawbacks limiting their industrial expansion are their low yields of production [188]. Approximately 30 species of lactobacilli are described as EPS producers, among them, the best known are L. casei, L. acidophilus, L. brevis, L. curvatus, L. delbrueckii bulgaricus, L. helveticus, L. rhamnosus, L. plantarum. They are principally cultivated between 30 and $37^{\circ} \mathrm{C}$ on rich media as Man Rogosa Sharp (MRS), milk or milk derivatives $[189,188]$. But Lactobacillus sp. are not the best polysaccharide pro- 
ducers compared to some soil bacteria, as Xanthomonas campestris [190,188]. It is known that different strains of $X$. campestris can produce xanthan gums of different composition, viscosity and yield. In reference [191], cheese whey was used as substrate in the production of xanthan gum with optimised high gum production in a bioreactor and at a wide range of viscosity values. With the strain X. campestris C7L, [192] a production level of $14.7 \mathrm{~g} \mathrm{~kg}^{-1}$ was obtained, in a $40 \mathrm{~g} \mathrm{~L}^{-1}$ whole milk whey-based medium (powdered cheese whey) with the addition of $0.1 \mathrm{~g} \mathrm{~L}^{-1}$ magnesium sulphate and $5 \mathrm{~g} \mathrm{~L}^{-1}$ potassium phosphate. In [193], the feasibility of using cheese whey as carbon source for xanthan gum production was investigated using two different strains: Xanthomonas campestris pv mangiferaeindicae 1230 and X. campestris pv manihotis 1182 . At $72 \mathrm{~h}$ of fermentation, using cheese whey as sole carbon source, in presence of $0.1 \%(\mathrm{w} / \mathrm{v}) \mathrm{MgSO}_{4}{ }^{*} 7 \mathrm{H}_{2} \mathrm{O}$ and $2.0 \%(\mathrm{w} / \mathrm{v})$ of $\mathrm{K}_{2} \mathrm{HPO}_{4}$, maximum xanthan gum productions were observed. Although the xanthan gum concentration was similar for the two strains, approximately $25 \mathrm{~g} \mathrm{~L}^{-1}$, chemical composition and ionic strength presented several differences.

A modelling approach was used to describe the influence of temperature and $\mathrm{pH}$ on the kinetics of both growth and EPS production of Streptococcus thermophilus ST 111 in milk-based medium; addition of whey protein hydrolysate to milk medium resulted in an increased growth and EPS production [194].

Growth and EPS production during free and immobilized cell chemostat culture of Lactobacillus rhamnosus RW-9595M D was described in [195]. Whey permeate powder was used, both very high EPS production (1800 $\left.\mathrm{mg} \mathrm{L}^{-1}\right)$ and volumetric productivity (542 $\left.\mathrm{mg} \mathrm{L}^{-1} \mathrm{~h}^{-1}\right)$ were obtained during chemostat culture with free cells for a D of $0.3 \mathrm{~h}^{-1}$.

\subsection{Bacteriocins}

Bacteriocins are antimicrobial peptides synthesized, at ribosomal level, by various Gram positive and and Gram negative bacteria, acting towards strictly correlated bacteria (growth inhibition). Generally, bacteriocins are produced at the end of the exponential growth-phase and their spectrum of action can vary, depending on the producing specie [196].

Positive effect of bacteriocins was spotlights in different types of food: dairy and bakery products, meat and fishing products, fruit and vegetables, beverage [197]. Moreover, further application are known, in medical, pharmaceutical and veterinary fields [198].

LAB are particularly prolific in bacteriocins production and can biosynthesize different types of antagonistic molecules. Many LAB are able to synthesize different classes of bacteriocins, currently, nysin is the only bacteriocin industrially produced and which use in food is allowed and authorized $[199,200]$. Over the last two decades, there has been an explosion of basic and applied research on lactic acid bacteria (LAB) bacteriocins, primarily due to their potential application as biopreservatives in food and food products to inhibit the growth of food-borne bacterial pathogens [196]. Different experimental models demonstrated efficiency on pathogens and spoilage microrganisms growth control, both adding bacteriocins in food [201,202] and using bacteriocins in situ synthesized [203]. 
Although bacteriocins can be produced in the food matrix during food fermentation (in situ), bacteriocins by LAB can be produced in much higher amounts during fermentations under optimal physical and chemical conditions [204-207].

A recent review [208] summarized information on nisin production by L. lactis in batch cultures utilizing skimmed milk or whey as inexpensive medium. Nisin biosynthesis occurs during the exponential growth phase, several cultural factors influence nisin production: producer strain, media composition, $\mathrm{pH}$ and temperature values, agitation and aeration. $\mathrm{Ni}$ sin production with Lactococcus lactis ATCC 11454 was carried out in two different media with pasteurized milk whey, filtered or not. In filtered milk whey nisin titer was 11120.13 $\mathrm{mgL}^{-1}$ up to 1628 -fold higher than the filtered milk whey. The higher nisin concentration was probably related to insoluble proteins released into the media [204]. In [209] the utilization of milk whey was studied in batch cultures, a higher nisin production was observed in diluted whey (mixed with wash waters), $22.9 \mathrm{BU} \mathrm{mL}^{-1}$ (BU - bacteriocin units) in relation to concentrated whey (liquid remaining after the first cheese pressing), 8.3 $\mathrm{BU} \mathrm{mL} \mathrm{m}^{-1}$.

In reference [205], the production of nisin by L. lactis UQ2 in a bioreactor using supplemented sweet whey (SW) was optimized by a statistical design of experiments and response surface methodology (RSM). A 2nd-order model built from a CCD experiment predicted a maximum nisin production of $178 \mathrm{IU} / \mathrm{mL}$ at $6 \mathrm{~h}$ of incubation in the bioreactor, leading to a productivity of $0.74 \mathrm{mg}$ nisin/([L][h]), which increased 1.62 times when using controlled $\mathrm{pH}$ (6.5) fermentation.

Continuous production of nisin in whey permeate, supplemented with casein hydrolysate, was investigated using a packed-bed bioreactor. Lactococcus lactis subsp. lactis ATCC 11454 was immobilized by natural attachment to fiber surfaces and entrapment in the void volume within spiral wound fibrous matrix. Optimal conditions for continuous nisin production were $\mathrm{pH} 5.5,31^{\circ} \mathrm{C}, 10-20 \mathrm{~g} / \mathrm{l}$ casein hydrolysate, and D $0.2 \mathrm{~h}^{-1}$. A maximum nisin titer of $5.1 \times$ $10^{4} \mathrm{AU} / \mathrm{ml}$ was observed. The bioreactor was operated continuously for 6 months without encountering any clogging, degeneration, or contamination problems [206].

Previously, nisin-Z production was studied during repeated-cycle $\mathrm{pH}$-controlled batch (RCB) cultures using Lactococcus lactis subsp. Lactis biovar. diacetylactis UL719 immobilized in k-carrageenan/locust bean gum gel beads in supplemented whey permeate $[210,211]$.

Bacillus bacteriocins are increasingly becoming more important due to their sometimes broader spectra of inhibition (as compared with most LAB bacteriocins), which may include Gram-negative bacteria, yeasts or fungi, in addition to Gram-positive species, some of which are known to be pathogenic to humans and/ or animals. Bacteriocins from Bacillus species offer a much broader spectrum of potential applications compared with LAB bacteriocins. The use of Bacillus bacteriocins in food preservation is just starting to be investigated [212]. A BLIS with a broad spectrum of activity against pathogenic and spoilage bacteria (L. monocytogenes, B. cereus and clinical isolates of Streptococcus spp.) was produced by B. licheniformis $\mathrm{P} 40$ when cheese whey concentration in the growth medium was about $70 \mathrm{~g} \mathrm{~L}^{-1}$ [213]. 
Pediocin production on whey by Pediococcus acidilactici NRRL B-5627 was described in [214], pediocin was obtained both in batch and re-alkalized fed-batch fermentations on diluted whey supplemented with $2 \%(\mathrm{w} / \mathrm{v})$ yeast extract.

\subsection{Single cell protein and single cell oil}

The term SCP refers to dried cells of microorganisms such as algae, actinomycetes, bacteria, yeast, molds, and higher fungi grown in large-scale culture systems for use as protein source in human food or animal feed. Among suitable microorganisms to be grown on whey lactose as a substrate for SCP production, more research work has been carried out on yeasts, in particular K. marxianus [215-217]. The use of lactose or whey as a carbon source for the production of yeast biomass is a simple treatment process for increasing the value of food industry co-products [14,218].

Biomass produced from both batch and continuous processes [219-221] is mostly used as animal feed supplement [215] but also in production of baker's yeast [217].

In reference [221] deproteinized sweet and sour cheese whey concentrates were investigated as substrates for the production of SCP with Kluyveromyces marxianus CBS6556 up to a 100-1 scale. Biomass concentrations up to $50 \mathrm{~g} \mathrm{l}^{-1}\left(\mathrm{Y}_{\mathrm{x} / \mathrm{s}}\right.$ 0.52) for sweet whey and $65 \mathrm{~g} \mathrm{l}^{-1}\left(\mathrm{Y}_{\mathrm{x} / \mathrm{s}} 0.48\right)$ for sour whey concentrates were obtained.

Use of whey or buttermilk supplemented with YE for the growth of thermophilic LAB was reported in [222]; cell yields and kinetic parameters obtained were comparable or better than those obtained from control media, which appear to be too expensive for growing LAB on an industrial scale.

High added value probiotic biomass from deproteinized and non-supplemented milk whey was reported in [223]. Growth kinetics of Lactobacillus casei in deproteinized goat milk whey was analyzed in batch, continuous and fed-batch conditions.

In [224] a technology for kefir SCP production using whey was developed, a three-step process to scale-up kefir biomass production at a semi industrial scale pilot plant (100- and 3,000L bioreactors) has been described.

The biotechnological production of SCO has been focused on the ability of various oleaginous microorganisms to convert agro-industrial wastes or raw materials into specialty lipids [225], or equivalents of plant oils that contain poly-unsaturated fatty acids (PUFAs) [226]. Three Zygomycetes, Mortierella isabellina, Thamnidium elegans and Mucor sp., were tested for their ability of producing biomass and lipid-containing g-linolenic acid (GLA) during their cultivation on cheese whey. All the tested microorganisms presented appreciable microbial growth; GLA concentration presented differences related with the strains and the fermentation time. M. isabellina produced noticeable quantities of SCO resulted in a maximum GLA production of $301 \mathrm{mg} / \mathrm{L}$ [227]. 


\subsection{Enzymes}

$\beta$-D-Galactosidase most commonly known as lactase, is one of the most important enzymes used in food processing, which catalyses the hydrolysis of lactose to glucose and galactose. The enzyme has been isolated and purified from a wide range of microorganisms but most commonly used $\beta$-D-galactosidases are derived from yeasts and fungal sources [228,229].

Yeast strains have been grown successfully on whey based medium among different strains of Kluyveromyces spp., K. marxianus and K. fragilis strains showed the maximum enzyme yield [230,14]. Streptococcus thermophiles and Bacillus stearothermophilus can be considered as potential bacterial sources of lactase. S. thermophilus was grown in deproteinized cheese whey [231], supplementation of whey and whey permeate basal media resulted in enhancement of specific growth rate and enzyme activity in bacterial cultures [232].

A simple feeding strategies to obtain high-cell-density cultures of K. marxianus (35 $\left.\mathrm{g} \mathrm{L}^{-1}\right)$ maximizing $\beta$-galactosidase productivity using cheese whey as basic medium was reported in reference [233].

A fermentation process for the production of penicillin acylase by a recombinant Escherichia coli and using whey as unique carbon was developed in [234].

Serratia marcescens ATCC 25419 was used for production of secreted proteases on reconstituted whey. A major metallo-protease and a minor serine protease were produced during growth [235]. In reference [236], a mixed culture Serratia marcescens-Kluyveromyces fragilis was tested on whey, microorganisms showed a synergistic effect in protease production.

\section{Author details}

Chiara Mollea, Luca Marmo and Francesca Bosco*

*Address all correspondence to: francesca.bosco@polito.it

Department of Applied Science and Technology, Politecnico di Torino. C.so Duca degli Abruzzi, 24, 10129 Torino, Italy

\section{References}

[1] Baldasso C., Barros T.C., Tessaro I.C. Concentration and purification of whey proteins by ultrafiltration. Desalination 2011;278 381-386.

[2] Spalatelu C. Biotechnological valorization of whey. Innovative Romanian Food Biotechnology 2012;10 1-8. 
[3] Koller M., Bona R., Braunegg G., Hermann C., Horvat P., Kroutil M., Martinz J., Neto J., Pereira L., Varila P. Production of Polyhydroxyalkanoates from Agricultural Waste and Surplus Materials. Biomacromolecules 2005;6 561-565.

[4] Panesar, P.S., Kennedy J.F., Gandhi D.N., Bunko K. Bioutilisation of whey for lactic acid production. Food Chemistry 2007;105 1-14.

[5] Jelen, P. Whey processing. In: H. Roginski, J. W. Fuquay, P. F. Fox (ed.) Encylcopedia of dairy sciences. London: Academic Press. 2003 p2739-2751.

[6] Prazeres A.R., Carvalho F., Rivas J. Cheese whey management: A review. Journal of Environmental Management 2012;110 48-68.

[7] Atra R., Vatai G., Bekassy-Molnar E., Balint A. Investigation of ultra- and nanofiltration for utilization of whey protein and lactose. Journal of Food Engineering 2005;67 325-332

[8] Barile D., Tao N., Lebrilla C.B., Coisson J-D., Arlorio M., German J.B. Permeate from cheese whey ultrafiltration is a source of milk oligosaccharides. International Dairy Journal 2009;19 524-530.

[9] Marshall K. Therapeutic Applications of Whey Protein. Altern Med Rev 2004; 9(2) 136-156.

[10] Huffman, L.M. Processing whey protein for use as a food ingredient. Food Technology $1996 ; 5049-52$.

[11] Mann E.J. Whey products and their uses. Dairy Industries International 2000; 13-14.

[12] Pouliot Y. Membrane processes in dairy technology-from a simple idea to worldwide panacea. International Dairy Journal 2008;18(7) 735- 740.

[13] deWit J.N. Nutritional and functional characteristics of whey proteins in food products, J. Dairy Science 1998;81 597-608.

[14] Siso, M.I.G. The biotechnological utilization of cheese whey: a review. Bioresource Technology 1996;57(1) 1-11

[15] Gunasekaran S., Ko S., Xiao L. Use of whey proteins for encapsulation and controlled delivery applications. Journal of Food Engineering 2007;83 31-40.

[16] López-Rubio A., Lagaron J.M. Whey protein capsules obtained through electrospraying for the encapsulation of bioactives. Innovative Food Science and Emerging Technologies 2012;13 200-206.

[17] Jovanovic S., Barac M., Macej O., Vucic T., Lacnjevac C. SDS-PAGE analysis of soluble proteins in reconstituted milk exposed to different heat treatments. Sensors 2007;7 371-383.

[18] Santos M.J., Teixeira J.A., Rodrigues L.R. Fractionation of the major whey proteins and isolation of beta-Lactoglobulin variants by anion exchange chromatography. Separation and Purification Technology 2012;90 133-139. 
[19] Evans E.W. Uses of milk proteins in formulated foods. In B.J.F. Hudson (Ed.), Developments in Food Proteins. London: Applied Science; 1982.

[20] Etzel M.R. Manufacture and use of dairy protein fractions. The Journal of Nutrition 2004;134 Suppl. 996S-1002S.

[21] Madureira A.R., Pereira C.I., Gomes A.M.P., Pintado M.E., Malcata F.X. Bovine whey proteins - Overview on the main biological properties. Food Research International 2007;40(10) 1197-1211.

[22] Huffman L.M., Harper W.J. Maximizing the value of milk through separation technologies. J. Dairy Sci. 1999;82 2238-2244.

[23] Zemel M.B. Role of calcium and dairy products in energy partitioning and weight management. American Journal of Clinical Nutrition 2004;79 907S-912S.

[24] Smilowitz J.T., Dillard C.J., German J.B. Milk beyond essential nutrients: The metabolic food. Australian Journal of Dairy Technology 2005;60 77-83.

[25] Krissansen G.W. Emerging health properties of whey proteins and their clinical implications. Journal of the American College of Nutrition 2007;26(6) 713S-723S.

[26] McIntosh G.H., Royle P.J., Le Leu R.K., Regester G.O., Johnson M.A., Grinsted R.L., Kenward R.S., Smithers G.W. Whey Proteins as Functional Food Ingredients? Int. Dairy Journal 1998;425-434.

[27] Shahidi F. Nutraceuticals and functional foods: whole versus processed foods. Trends in Food Science and Technology 2009;20 376-387.

[28] Kaur S., Das M. Functional foods: an overview. Food Sci. Biotechnol. 2011;20(4) 861-875.

[29] Hardy G. Nutraceuticals and Functional Foods: Introduction and Meaning. Nutrition 2000;16 688-698.

[30] Bonnaillie, L.M., Tomasula, P.M., Kinetics, aggregation behavior and optimization of the fractionation of whey protein isolate with hydrochloric acid. Food Bioprod Process 2012;doi:10.1016/j.fbp.2012.01.002

[31] Lozano J.M., Giraldo G.I., Romero C.M. An improved method for isolation of $\beta$-lactoglobulin. International Dairy Journal 2008;18 55-63.

[32] Wang Q., Tolkach A., Kulozik U. Quantitative assessment of thermal denaturation of bovine alfa-lactalbumin via low-intensity ultrasound, HPLC, and DSC. J. Agric. Food Chem. 2006;54 6501-6506.

[33] Fernandez A., Menendez V., Riera F.A., Alvarez R. Caseinomacropeptide behaviour in a whey protein fractionation process based on alpha-lactalbumin precipitation. J. Dairy Res. 2011;78 196-202.

[34] Zydney, A.L. Protein separation using membrane filtration: new opportunities for whey fractionation. Int. Dairy J. 1998;8 243-250. 
[35] Smithers G.W., Ballard F.J., Copeland A.D., De Silva K.J., Dionysius D.A., Francis G.L., et al. Symposium: advances in dairy foods processing and engineering. J. Dairy Sci. 1996;79 1454-1459.

[36] Almecija M.C., Ibanez R., Antonio Guadix A., Guadix E.M. Effect of pH on the fractionation of whey proteins with a ceramic ultrafiltration membrane. Journal of Membrane Science 2007;288 28-35.

[37] Gurgel P.V., Carbonell R.G., Swaisgood H.E. Fractionation of whey proteins with a hexapeptide ligand affinity resin. Bioseparation 2000;9 385.

[38] Noppe W., Haezebrouck P., Hanssens I., De Cuyper M. Asimplified purification procedure of alpha-lactalbumin from milk using Ca2+-dependent adsorption in hydrophobic expanded bed chromatography. Bioseparation 1999;8 153.

[39] Wang Q., Swaisgood H.E. Characteristics of beta-lactoglobulin binding to the alltrans-retinal moiety covalently immobilized on Celite ${ }^{\mathrm{TM}}$. J. Dairy Sci. 1993;76 18951901.

[40] Schlatterer B., Baeker R., Schlatterer K. Improved purification of $\beta$-lactoglobulin from acid whey by means of ceramic hydroxyapatite chromatography with sodium fluoride as a displacer. J. of Chromatography B 2004;807 223-228.

[41] Doultani S., Turhan K.N., Etzel M.R. Fractionation of proteins from whey using cation exchange chromatography. Process Biochemistry 2004;37 1737-1743.

[42] Lightfoot E.N., Cockrem M.C.M. What are dilute-solutions. Sep. Sci. Technol. 1987;22 165-189.

[43] Heeboll-Nielsen A., Justesen S.F.L., Thomas O.R.T. Fractionation of whey proteins with high-capacity superparamagnetic ion-exchangers, J. Biotechnol. 2004;113 247.

[44] Sawyer L. $\beta$-Lactoglobulin. Pages 319-386 in Advanced Dairy Chemistry I, 3rd ed. P. F. Fox and P. McSweeney, eds. Kluwer, Amsterdam, The Netherlands; 2003.

[45] Kontopidis G., Holt C., Sawyer L. Invited Review: $\beta$-Lactoglobulin: Binding Properties, Structure, and Function. Journal of Dairy Science 2004;87(4) 785-796.

[46] Ragona L., Catalano M., Zetta L., Longhi R., Fogolari F., Molinari H. Peptide models of folding initiation sites of bovine b-lactoglobulin: Identification of native like hydrophobic interactions involving G and H strands. Biochemistry 2002;41 2786-2796.

[47] Apenten R.K.O., Khokhar S., Galani D. Stability parameters for b-lactoglobulin. Thermal dissociation and unfolding in phosphate buffer at $\mathrm{pH}$ 7. Food Hydrocolloids 2002;16 95-103.

[48] Perez M.D., Calvo M. Interaction of beta-lactoglobulin with retinol and fatty acids and its role as a possible biological function for this protein: a review. J. Dairy Sci. 1995;78 978-988. 
[49] Yoshida T., Sasahara Y., Miyakawa S., Hattori M. Reduced T cell response to betalactoglobulin by conjugation with acidic oligosaccharides. J. Agric. Food Chem. 2005;53 6851-6857.

[50] Adel-Patient K., Ah-Leung S., Creminon C., Nouaille S., Chatel J.M., Langella P., Wal J.M. Oral administration of recombinant Lactococcus lactis expressing bovine betalactoglobulin partially prevents mice from sensitization. Clin. Exp. Allergy 2005;35 539-546.

[51] Cortes-Perez N.G., Ah-Leung S., Bermudez-Humaran L.G., Corthier G., Wal J.M., Langella P., Adel-Patient K. Intranasal coadministration of live lactococci producing interleukin-12 and a major cow's milk allergen inhibits allergic reaction in mice. Clin. Vaccine Immunol. 2007;14 226-233.

[52] Prioult G., Pecquet S., Fliss I. Stimulation of interleukin-10 production by acidic betalactoglobulin-derived peptides hydrolyzed with Lactobacillus paracasei NCC2461 peptidases. Clin. Diagn. Lab. Immunol. 2004;11 266-271.

[53] Kushibiki S., Hodate K., Kurisaki J., Shingu H., Ueda Y., Watanabe A., Shinoda M. Effect of beta-lactoglobulin on plasma retinol and triglyceride concentrations, and fatty acid composition in calves. J. Dairy Res. 2001;68 579-586.

[54] Meisel H. Biochemical properties of peptides encrypted in bovine milk proteins. Curr. Med. Chem. 2005;12 1905-1919.

[55] Sipola M., Finckenberg P., Vapaatalo H., Pihlanto-Leppala A., Korhonen H., Korpela R., Nurminen M.L. Alpha-lactorphin and beta-lactorphin improve arterial function in spontaneously hypertensive rats. Life Sci. 2002;71 1245-1253.

[56] Yamauchi R., Wada E., Yamada D., Yoshikawa M., Wada K.: Effect of beta-lactotensin on acute stress and fear memory. Peptides 2006;27 3176-3182.

[57] Ohinata K., Sonoda S., Inoue N., Yamauchi R., Wada K., Yoshikawa M. beta-Lactotensin, a neurotensin agonist peptide derived from bovine beta-lactoglobulin, enhances memory consolidation in mice. Peptides 2007;28 1470-1474.

[58] Yamauchi R., Ohinata K., Yoshikawa M. Beta-lactotensin and neurotensin rapidly reduce serum cholesterol via NT2 receptor. Peptides 2003;24 1955-1961.

[59] Barbana C., Pérez M.D. Interaction of a-lactalbumin with lipids and possible implications for its emulsifying properties: A review. International Dairy Journal 2011;21 727-741.

[60] Grobler J.A., Wang M., Pike A.C., Brew K. Study by mutagenesis of the roles of two aromatic clusters of a-lactalbumin in aspects of its action in the lactose synthase system. Journal of Biological Chemistry 1994;269 5106-5114.

[61] Brew K. alfa-Lactalbumin. In P. F. Fox, \& P. L. H. McSweeney (Eds.), Proteins (3rd ed.). Advanced dairy chemistry, Vol. I (pp. 387e421) New York, NY, USA: Kluwer Academic/Plenum Press;2003. 
[62] Lien E.L. Infant formulas with increased concentrations of a-lactalbumin. American Journal of Clinical Nutrition 2003;77 1555S-1558S.

[63] Wijesinha-Bettoni R., Dobson C.M., Redfield C. Comparison of the structural and dynamical properties of holo and apo bovine a-lactalbumin by NMR spectroscopy. Journal of Molecular Biology 2001;307 885-898.

[64] Pettersson-Kastberg J., Mossberg A.K., Trulsson M., Yong Y.J., Min S., Lim Y. alfaLactalbumin, engineered to be nonnative and inactive, kills tumor cells when in complex with oleic acid: a new biological function resulting from partial unfolding. Journal of Molecular Biology 2009;394 994-1010.

[65] Noyelle K., Van Dael H. Kinetics of conformational changes induced by the binding of various metal ions to bovine a-lactalbumin. Journal of Inorganic Biochemistry 2002;88 69-76.

[66] Owusu R.K. The effect of calcium on bovine a-lactalbumin conformational transitions by ultraviolet difference and fluorescence spectrophotometry. Food Chemistry 1992a; 43 41-45.

[67] Owusu R.K. Thermodynamic analysis of the effect of calcium on bovine a-lactalbumin conformational stability. Food Chemistry 1992b;44 189-194.

[68] Stanciuc N., Rapeanu G. An overwiev of bovine $\alpha$-lactalbumin structure and functionality. Food Technology 2010;34(2) 82-93.

[69] Otani H., Mizumoto G.. Suppressive effect of lysozymes and $\alpha$-lactalbumins on mitogen-induced proliverative responses of mouse lymphocytes. Animal Science Technology 1998;11 1029-1039.

[70] Matsumoto H., Shimokawa Y., Ushida Y., Toida T., Hayasawa H. New biological function of bovine $\alpha$-lactalbumin: Protective effect against ethanol- and stress-induced gastric mucosal injury in rats. Bioscience, Biotechnology and Biochemistry 2001;65 1104-1111.

[71] Heine W.E., Klein P.D., Reeds P.J. The importance of $\alpha$-lactalbumin in infant nutrition- Critical Review. The Journal of Nutrition 1991;121 277-283.

[72] Maubois J.L., Ollivier G. Extraction of milk proteins. In S. Damodaran, A. Paraf (Eds.), Food proteins and their applications (pp. 225-256). New York, NY, USA: Marcel Dekker;1997. p225-256.

[73] Gustafsson L., Hallgren O., Mossberg A. K., Pettersson J., Fischer W., Aronsson A. HAMLET kills tumour cells by apoptosis: Structure, cellular mechanisms and therapy. Journal of Nutrition 2005;135 1299-1303.

[74] Pellegrini A., Thomas U., Bramaz N., Hunziker P., von Fellenberg R., Isolation and identification of three bactericidal domains in the bovine $\alpha$-lactalbumin molecule. Biochimica et Biophysica Acta- General Subjects 1999;1426(3) 439-448. 
[75] Teschemacher H., Koch G., Brantl V. Milk protein-derived opioid receptor ligands. Peptide Science 1998;43(2) 99-117.

[76] Yamaguchi M. and Uchida M. $\alpha$-Lactalbumin suppresses interleukin-6 release after intestinal ischemia/reperfusion via nitric oxide in rats. Inflammopharmacology 2007;15 43-47.

[77] Gauthier S.F., Pouliot Y., Saint-Sauveur D. Immunomodulatory peptides obtained by the enzymatic olysis of whey proteins-Review. International Dairy Journal 2006;16 1315-1323.

[78] de Wit J.N. Functional properties of whey proteins. In Developments of dairy chemistry. In P. F. Fox (Ed.). Functional milk proteins (Vol. 4). London: Applied Science; 1989.

[79] Korhonen H., Marnila P., Gill H. Milk immunoglobulins and complement factors: A review. British Journal of Nutrition 2000;84 S1-S7.

[80] Mulvihill D.M., Donovan M. Whey proteins and their thermal denaturation - a review. Irish Journal of Food Science and Technology 1987;11 43-75.

[81] Sarker S.A., Casswall T.H., Mahalanabis D., Alam N.H., Albert M.J., Brussow H., et al. Successful treatment of rotavirus diarrhoea in children with immunoglobulin from immunised bovine colostra. Peadiatric Infectious Diseases Journal 1998;17 1149-1154.

[82] Zenk J.L., Helmer T.R., Kuskowski M.A. The effects of milk protein concentrate on the symptoms of osteoarthritis in adults: An exploratory, randomized, double-blind, placebo-controlled trial. Curr. Ther. Res. 2002;63 430-442.

[83] Oona M., Rago T., Maaroos H., Mikelsaar M., Loivukene K., Salminen S., et al. Helicobacter pylori in children with abdominal complaints: Has immune bovine colostrum some influence on gastritis? Alpe Adria Microbiology Journal 1997;6 49-57.

[84] Loimaranta V., Laine M., Soderling E., Vasara E., Rokka S., Marnila P., et al. Effects of bovine immune- and non-immune whey preparations on the composition and $\mathrm{pH}$ response of human dental plaque. European Journal of Oral Science 1999;107 244-250.

[85] Ormrod D.J., Miller T.E. The anti-inflammatory activity of a low molecular weight component derived from the milk of hyperimmunized cows. Agents and Actions 1991;32 160-166.

[86] Korhonen H., Syvaoja E., Ahola-Luttila H., Sivela S., Kopola S., Husu J., et al. Bactericidal effect of bovine normal and immune serum, colostrum and milk against Helicobacter pylori. Journal of Applied Bacteriology 1995;78 655-662.

[87] Sharpe S.J., Gamble G.D., Sharpe D.N. Cholesterol lowering and blood pressure effects of immune milk. American Journal of Clinical Nutrition 1994;59 929-934. 
[88] Huang B.X., Kim H., Dass C. Probing three-dimensional structure of bovine serum albumin by chemical cross-linking and mass spectrometry. J. Am. Soc. Mass. Spectrom. 2004;15 1237-1247.

[89] Fox P.F. The milk protein system. In Developments in Dairy Chemistry. In P. F. Fox (Ed.). Functional Milk Proteins (Vol. 4). London: Applied Science;1989.

[90] Kinsella J.E., Whitehead D.M., Brady J., Bringe N.A. Milk proteins, possible relationships of structure and function. In Developments in Dairy Chemistry. In P. F. Fox (Ed.). Functional Milk Proteins (Vol. 4). London: Applied Science;1989.

[91] Laursen I., Briand P., Lykkesfeldt A.E. Serum albumin as a modulator of the human breast cancer cell line MCF-7. Anticancer Research 1990;10 343-352.

[92] Lu B., Xiong S., Yang H., Yin X., Zhao R. Mitoxantrone-loaded BSA nanospheres and chitosan nanospheres for local injection against breast cancer and its lymph node metastases II: Tissue distribution and pharmacodynamics. International Journal of Pharmaceutics 2006;307 175-181.

[93] Choi J.K., Ho J., Curry S., Qin D., Bittman R., Hamilton J.A. Interactions of very longchain saturated fatty acids with serum albumin. Journal of Lipid Research 2002;43 1000-1010.

[94] Tong L.M., Sasaki S., McClements D.J., Decker E.A. Mechanisms of the antioxidant activity of a high molecular weight fraction of whey. Journal of Agricultural and Food Chemistry 2000;48 1473-1478.

[95] Adlerova L., Bartoskova A., Faldyna M. Lactoferrin: a review. Veterinarni Medicina 2008;53 9 457-468.

[96] Sharma S., Jasti J., Kumar J., Mohanty A.K., Singh T.P. Crystal structure of a proteolytically generated functional monoferric C-lobe of bovine lactoferrin at $1.9 \mathrm{~A}$ resolution. J. Mol. Biol. 2003;331 485-496.

[97] Brock J.H. The physiology of lactoferrin. Biochemistry and Cell Biology 2002;80 1-6.

[98] Van Snick J.L., Masson P.L., Heremans J.F. The involvement of lactoferrin in the hyposideremia of acute inflammation. The Journal of Experimental Medicine 1974;140 1068-1084.

[99] Van Vugt H., Van Gool J., Ladiges N.C., Boers W. Lactoferrin in rabbit bile: its relation to iron metabolism. Quarterly Journal of Experimental Physiology and Cognate Medical Sciences 1975;60 79-88.

[100] Suzuki Y.A., Lopez V., Lonnerdal B. Mammalian lactoferrin receptors: structure and function. Cellular and Molecular Life Sciences 2005;62 2560-2575.

[101] Legrand D., Elass E., Carpentier M., Mazurier J. Lactoferrin: a modulator of immune and inflammatory responses. Cellular and Molecular Life Sciences 2005;62 25492559 . 
[102] Brock J.H. Lactoferrin in human milk: its role in iron absorption and protection against enteric infection in the newborn infant. Archives of Disease in Childhood 1980;55 417-421.

[103] Sherman M.P., Bennett S.H., Hwang F.F., Yu C. Neonatal small bowel epithelia: enhancing anti-bacterial defense with lactoferrin and Lactobacillus GG. Biometals 2004;17 285-289.

[104] Rossi P., Giansanti F., Boffi A., Ajello M., Valenti P., Chiancone E., Antonini G. Ca2+ binding to bovine lactoferrin enhances protein stability and influences the release of bacterial lipopolysaccharide. Biochemistry and Cell Biology 2002;80 41-48.

[105] Valenti P., Antonini G. Lactoferrin: an important host defense against microbial and viral attack. Cellular and Molecular Life Sciences 2005;62 2576-2587.

[106] Ward P.P., Paz E., Conneely O.M. Multifunctional roles of lactoferrin: a critical overview. Cellular and Molecular Life Sciences 2005;62 2540-2548.

[107] Yi M., Kaneko S., Yu D.Y., Murakami S. Hepatitis C virus envelope proteins bind lactoferrin. Journal of Virology 1997;71 5997-6002.

[108] Damiens E., El Yazidi I., Mazurier J., Duthille I., Spik G., Boilly-Marer Y. Lactoferrrin inhibits G1 cyclin-dependent kinases during growth arrest of human breast carcinoma cells. Journal of Cellular Biochemistry 1999;74 486-498.

[109] Damiens E., Mazurier J., El Yazidi I., Masson M., Duthille I., Spik G., Boilly-Marer Y. Effects of human lactoferrin on NK cell cytotoxicity against haematopoetic and epithelial tumour cells. Biochimica et Biophysica Acta1998;1402 277-287.

[110] Fujita K., Matsuda E., Sekine K., Iigo M., Tsuda H. Lactoferrin enhances Fas expression and apoptosis in the colon mucosa of azoxymethane-treated rats. Carcinogenesis 2004;25 1961-1966.

[111] Yanaihara A., Toma Y., Saito H., Yanaihara T. Cell proliferation effect of lactoferrin in human endometrial stroma cells. Molecular Human Reproduction 2000;6 469-473.

[112] He J., Furmanski P. Sequence specificity and transcriptional activation in the binding of lactoferrin to DNA. Nature 1995;373 721-724.

[113] Cornish J., Callon K.E., Naot D., Palmano K.P., Banovic T., Bava U., Watson M., Lin J.M., etc. Lactoferrin is a potent regulator of bone cell activity and increases bone formation in vivo. Endocrinology 2004;145 4366-4374.

[114] Reiter B., Perraudin J.P. Lactoperoxidase, biological functions. In J. Everse, K. E. Everse, \& M. B. Grisham (Eds.). Peroxidases in Chemistry and Biology. Boca Raton, FL: CRC Press;1991. Vol.1 p144-180.

[115] Watanabe S., Murata S., Kumura H., Shingo Nakamura S., Bollen A., Moguilevsky N., Shimazaki K. Bovine Lactoperoxidase and Its Recombinant: Comparison of Structure and Some Biochemical Properties. Biochemical and Biophysical Research Communications 2000;274 756-761. 
[116] Reiter B., Pickering A., Oram J. D., Pope G.S. Peroxidase thiocyanate inhibition of streptococci in raw milk. Journal of General Microbiology 1963;33 12-15.

[117] Tenovuo J. Clinical applications of antimicrobial host proteins lactoperoxidase, lysozyme and lactoferrin in xerostomia: efficacy and safety. Oral Diseases 2002;8 23-29.

[118] Touch V., Hayakawa S., Yamada S., Kaneko S. Effects of a lactoperoxidase-thiocyanate-hydrogen peroxide system on Salmonella enteritidis in animal or vegetable foods. International Journal of Food Microbiology 2004;93 175- 183.

[119] Wolfson L.M. and Sumner S.S. Antibacterial activity of the lactoperoxidase system. A review. J. Food Prot. 1993;56 887-892.

[120] de Wit J.N. and van Hooydonk A.C.M. Structure, functions and application of lactoperoxidase in natural antimicrobial system. Netherland Milk Dairy J. 1996;50 227-244.

[121] Seifu E., Buys E.M. and Donkinc E.F. Significance of the lactoperoxidase system in the dairy industry and its potential applications: a review. Trends in Food Science \& Technology 2005;16 137-154.

[122] Reiter B.V., Marshall M.E., Bjorck L., Rosen C.G. Non specific bactericidal activity of the lactoperoxidase - thyocianate - hydrogen peroxide system on milk against Escherichia coli and some Gram negative pathogens. Infect. Immun. 1976;13 800-807.

[123] Carlsson J., Iwami Y., Yamada, T. Hydrogen peroxide excretion by oral streptococci and effect of lactoperoxidase- thiocyanate-hydrogen peroxide. Infection and Immunity $1983 ; 40$ 70-80.

[124] Tenovuo J., Makinen K.K., Sievers G. Antibacterial effect of lactoperoxidase and myeloperoxidase against Bacillus cereus. Antimicrobial Agents and Chemotherapy 1985;27 96-101.

[125] Pruitt K.M., Kamau D.N. The lactoperoxidase system of bovine and human milk. In D. S. Robinson, \& N. A. M. Eskin (Eds.), Oxidative enzymes in foods. London: Elsevier Applied Science;1991. p133-174.

[126] Garcia-Graells C., van Opstal I., Vanmuysen S.C. M., Michiels C.W. The lactoperoxidase system increases efficacy of high-pressure inactivation of foodborne bacteria. International Journal of Food Microbiology 2002;81 211-221.

[127] Seifu E., Buys E.M., Donkin E.F., Petzer, I.M. Antibacterial activity of the lactoperoxidase system against foodborne pathogens in Saanen and South African Indigenous goat milk. Food Control 2004b;15 447-452.

[128] Jacob B.M., Antony E.K., Sreekumar, B., Haridas M. Thiocyanate mediated antifungal and antibacterial property of goat milk lactoperoxidase. Life Sciences 2000;66 24332439 .

[129] Belding M. E., Klebanoff S. J., Ray G.C. Peroxidase mediated virucidal systems. Science 1970;167 195-196. 
[130] Yamaguchi Y., Semmel M., Stanislawski L., Strosberg A.D., Stanislawski M. Virucidal effects of glucose oxidase and peroxidase or their protein conjugates on human immunodeficiency virus type 1. Antimicrobial Agents and Chemotherapy 1993,37 2631.

[131] Pourtois M., Binet C., Van Tieghem N., Courtois P., Vandenabbeele A., Thiry L. Inhibition of HIV infectivity by lactoperoxidase-produced hypothiocyanite. Journal de Biologie Buccale 1990;18 251-253.

[132] Kosikowsky F.V. Whey utilization and whey products. J. Dairy Science 1979;62(7) 1149-1160.

[133] Zafar S., Owais M. Ethanol production from crude whey by Kluyveromyces marxianus. Biochemical Engineering J. 2006;27 295-298.

[134] Sansonetti S., Curcio S., Calabrò V., Iorio G. Bio-ethanol production by fermentation of ricotta cheese whey as an effective alternative non-vegetable source. Biomass Bioenergy 2009;33(12) 1687-1692.

[135] Guimarães P.M.R., François J., Parrou J.L., Teixeira J.A., Domingues L. Adaptive evolution of a lactose-consuming Saccharomyces cerevisiae recombinant. Applied Environmental Microbiology 2008;74(6) 1748-1756.

[136] Guimarães P.M.R., Teixeira J.A., Domingues L. Research review paper: fermentation of lactose to bio-ethanol by yeasts as part of integrated solutions for the valorisation of cheese whey. Biotechnology Advances 2010;28(3) 375-384.

[137] Anderson A.J., Dawes E.A. Occurrence, Metabolism, Metabolic Role, and Industrial Uses of Bacterial Polyhydroxyalkanoates. Microbiological Reviews 1990;54(4) 450-472.

[138] Khanna S., Srivastava A.K. Recent advances in microbial polyhydroxyalkanoates. Process Biochemistry 2005;40 607-619.

[139] Reddy C.S., Ghai R., Rashmi, Kalia V.C. Polyhydroxylakanoates: an overview. Bioresource Technology 2003;87 137-146.

[140] Sudesh K., Abe H., Doi Y. Synthesis, structure and properties of polyhydroxyalkanoates: biological polyesters. Progress Polymer Science 2000;25 1503-1555.

[141] Koller M., Hesse P., Bona R., Kutschera C., Atlic A., Braunegg G. Potential of various archae- and eubacterial strains as industrial polyhydroxyalkanoate producers from whey. Macromol. Biosci. 2007;7 218-226.

[142] Marangoni C., Furigo A. Jr., de Aragão G.M.F. Production of poly(3-hydroxybutyrate-co-3-hydroxyvalerate) by Ralstonia eutropha in whey and inverted sugar with propionic acid feeding. Process Biochemistry 2002;38 137-141.

[143] Koller M., Bona R., Chiellini E., Grillo Fernandes E., Horvat P., Kutscher C., Hesse P., Braunegg G. Polyhydroxyalkanoate production from whey by Pseudomonas hydrogenovora. Bioresource Technology 2008;99 4854-4863. 
[144] Wong H.H., Lee S.Y. Poly(3-hydroxybutyrate) production from whey by high density cultivation of recombinant Escherichia coli. Applied Microbiology Biotechnology 1998;50 30-33.

[145] Nikel P.I., Almeida A.D., Melillo E.C., Galvagno M.A., Pettinari M.J. New recombinant Escherichia coli strain tailored for the production of poly(3-hydroxybutyrate) from agro-industrial by-products. Applied Environmental Microbiology 2006;72 3949-3954.

[146] Yellore V., Desai A. Production of poly-3-hydroxybutyrate from lactose and whey by Methylobacterium sp. ZP24. Letters in Applied Microbiology 1998;26 391-394.

[147] Aslım B., Çalışkan F., Beyatli Y., Gündüz U. Poly- $\beta$-hydroxybutyrate production by lactic acid bacteria. FEMS Microbiology Letters 1998;159 293-297.

[148] Tanaka K., Katamune K., Ishizaki A. Fermentative production of poly-( $\beta$-hydroxybutyric acid) from xylose via L-lactate by a two stage culture method employing Lactococcus lactis IO-1 and Alcaligenes eutrophus. Canadian J. Microbioliology 1995;41 257261.

[149] Tohyama M., Patarinska T., Qiang Z., Shimizu K. Modeling of the mixed culture and periodic control for PHB production. J. Biochemical Engineering 2002;10 157-173.

[150] Tohyama M., Shimizu K. Control of a mixed culture of Lactobacillus delbrueckii and Ralstonia eutropha for the production of PHB from glucose via lactate. J Biochemical Engineering 1999;4 45-53.

[151] Tohyama M., Takagi S., Shimizu K. Effect of controlling lactate concentration and periodic change in $\mathrm{DO}$ concentration on fermentation characteristics of a mixed culture of Lactobacillus delbrueckii and Ralstonia eutropha for PHB production. J. Bioscience Bioengineering 2000;89 323-328.

[152] Patnaik P.R. Perspectives in the modelling and optimization of PHB production by pure and mixed cultures. Critical Reviews in Biotechnology 2005;25 153-171.

[153] Bader J., Mast-Gerlach E., Popovic M.K., Bajpai R., Stahl U. Relevance of microbial co-culture fermentations in biotechnology. Journal of Applied Microbiology 2010;109 371-387.

[154] Yilmaz M., Soran H., Beyatli Y. Determination of poly-b-hydroxybutyrate (PHB) production by some Bacillus spp. World J. Microbiology Biotechnology 2005; 21 565-566.

[155] Defoirdt T., Boon N., Sorgeloos P., Verstraete W., Bossier P. Short-chain fatty acids and poly- $\beta$-hydroxyalkanoates: (New) Biocontrol agents for a sustainable animal production. Biotechnology Advances 2009;27 680-685.

[156] Yang N., Silva E.M., Novel products and new technologies for use of a familiar carbohydrate, milk lactose. J. Dairy Science 1995;78 2541-2562. 
[157] Pauli T., Fitzpatrick, J. J. Malt combing nuts as a nutrient supplement to whey permeate for producing lactic by fermentation with Lactobacillus casei. Process Biochemistry 2002;38 1-6.

[158] Roukas T., Kotzekidou P. Lactic acid production from deproteinized whey by mixed cultures of free and coimmobilized Lactobacillus casei and Lactococcus lactis cells using fedbatch culture. Enzyme and Microbial Technology 1998;22(3) 199-204.

[159] Tango M.S.A., Ghali A.E. Effect of temperature on lactic acid production from cheese whey using Lactobacillus helveticus under batch conditions. Biomass and Bioenergy 1999; 16(1) 61-78.

[160] John P.R., Nampoothiri K.M., Pandey A. Fermentative production of lactic acid from biomass: an overview on process developments and future perspectives. Applied Microbiology Biotechnology 2007;74 524-534.

[161] Dana R. Biodegradable packaging materials for food products. Scientific and Technical Bulletin of University “A.Vlaicu” Arad 2005;10 88-93.

[162] Lim L.T., Auras R., Rubino M. Processing technologies for poly(lactic acid). Progress in Polymer Science 2008;33: 820-852.

[163] Weber C.J., Haugaard V., Festersen R., Bertelsen G. Production and applications of biobased packaging materials for the food industry. Food Additive Contaminations 2002;19 172-177.

[164] Comstock K., Farrell D., Godwin C., Xi Y. From hydrocarbons to carbohydrates: food packaging of the future. 2004; Website: http://depts.washington.edu/poeweb/gradprograms/envmgt/mposium/GreenPackagingReport.pdf (Accessed 3/28/06).

[165] Arasaratnam V., Senthuran A., Balasubramaniam K. Supplementation of whey with glucose and different nitrogen sources for lactic acid production by Lactobacillus delbrueckii. Enzyme and Microbial Technology 1996;19 482-486.

[166] Mostafa N.A. Production of lactic acid from whey with agar immobilized cells in a continuous packed tubular reactor. Energy and conversion management 1996;37(3) 253-260.

[167] Pescuma M., Hebert E.M., Mozzi F., de Valdez G.F. Whey fermentation by thermophilic lactic acid bacteria: Evolution of carbohydrates and protein content. Food Microbiology, 2008;25 442-451.

[168] Plessas S., Fischer A., Koureta K., Psarianos C., Nigam P., Koutinas A.A. Application of Kluyveromyces marxianus, Lactobacillus delbrueckii ssp. bulgaricus and L. helveticus for sourdough bread making. Food Chemistry 2008;106(1) 985-990.

[169] Vasala A., Panula J., Neubauer P. Efficient lactic acid production from high salt containing dairy by-products by Lactobacillus salivarius ssp. salicinius with pre-treatment by proteolytic microorganisms. Journal of Biotechnology 2005;117 421-31. 
[170] Gonzalez M.I., lvarez S. A., Riera F., Alvarez R. Economic evaluation of an integrated process for lactic acid production from ultrafiltered whey. Journal of Food Engineering 2007;80 553-561.

[171] Kulozik U., Wilde J. Rapid lactic acid production at high cell concentration in whey ultrafiltrate by Lactobacillus helveticus. Enzyme and Microbial Technology 1999;24(5-6) 297-302.

[172] Schepers A.W., Thibault J., Lacroix C. Lactobacillus helveticus growth and lactic acid production during $\mathrm{pH}$-controlled batch cultures in whey permeate/yeast extract medium. Part I: multiple factor kinetic analysis. Enzyme and Microbial Technology 2002;30 176-186.

[173] Roy D., Goulet J., LeDuy A. Batch fermentation of whey ultrafiltrate by Lactobacillus helveticus for lactic acid production. Applied Microbiol. Biotechnol. 1986; 24 206-13.

[174] Amrane A., Prigent Y. Influence of yeast extract concentration on batch cultures of Lactobacillus helveticus: growth and production coupling. World J. of Microb. Biot. 1993;14 529-34.

[175] Roy D., Goulet J., LeDuy A. Continuous production of lactic acid from whey permeate by free and calcium alginate entrapped Lactobacillus bulgaricus. J. Dairy Science 1987;70 506-13.

[176] Taguchi H., Ohta T. Cloning, sequencing and expression in Escherichia coli of the Dlactate dehydrogenase gene of Lactobacillus plantarum: D-lactate dehydrogenase is a member of the D-isomer-specific 2-hydroxyacid-dehydrogenase family. Journal of Biological Chemistry 1991;266(12) 588-594.

[177] Adachi E., Mikiko T., Sugiyama M., Nikawa J.I., Schimuzu K. Modification of metabolic pathways of Saccharomyces cerevisiae by the expression of lactate dehydrogenase and deletion of pyruvate decarboxylase genes for the lactic acid fermentation at low pH value. Journal of Fermentation and Bioengineering. 1998;86 284-289.

[178] Porro D., Bianchi M.M., Brambilla L., Meneghini R., Bolzani D., Carrera V. Replacement of a metabolic pathway for large-scale production of lactic acid from engineered yeast. Applied and Environmental Microbiology 1999;65 4211-4215.

[179] Bai D.M., Zhao X.M., Li X.G., Xub S.M. Strain improvement of Rhyzopus oryzae for over-production of L-(+)-lactic acid and metabolic flux analysis of mutans. Biochemical Engineering Journal 2004;18 41-48.

[180] De Vuyst L., Degeest B. Heteropolysaccharides from lactic acid bacteria. FEMS Microbiology Review 1999;23 153-177.

[181] van Hijum S.A.F.T., Kralj S., Ozimek L. K., Dijkhuizen L., van Geel-Schutten I.G. Structure-function relationships of glucansucrase and fructansucrase enzymes from lactic acid bacteria. Microbiol. Mol. Biol. Rev. 2006;70 157-176. 
[182] De Vuyst L., De Vin F., Vaningelgem F., Degeest B. Recent developments in the biosynthesis and applications of heteropolysaccharides from lactic acid bacteria. International Dairy J. 2001;11 687-707.

[183] Krinos C. M., Coyne M. J., Weinacht K.G., Tzianabos A.O., Kasper D.L., Comstock L.E. Extensive surface diversity of a commensal microorganism by multiple DNA inversions. Nature 2001;414 555-558.

[184] Patel S., Majumder A., Goyal A.. Potentials of Exopolysaccharides from Lactic Acid Bacteria. Indian J. Microbiology 2012;52(1) 3-12

[185] Makino S., Ikegami S., Kano H., Sashihara T., Sugano H., Horiuchi H., Saito T., Oda M. Immunomodulatory effects of polysaccharides produced by Lactobacillus delbrueckii spp. bulgaricus OLL1073R-1. J. Dairy Science 2006;89 2873-2881.

[186] Broadbent J.R., McMahon D.J., Welker D.L., Oberg C.J., Moineau S. Biochemistry, Genetics, and Applications of Exopolysaccharide. Production in Streptococcus thermophilus: A Review. J. Dairy Science 2003;86 407-423.

[187] Laws A.P., Marshall V.M. The relevance of exopolysaccharides to the rheological properties in milk fermented with ropy strains of lactic acid bacteria. International Dairy J. 2001;11 709-721.

[188] Badel S., Bernardi T., Michaud P. New perspectives for Lactobacilli exopolysaccharides. Biotechnology Advances 2011;29 54-66.

[189] Looijesteijn P.J., Hugenholtz J. Uncoupling of growth and exopolysaccharide production by Lactobacillus lactis subsp. cremoris NIZO B40 and optimization of its synthesis. Journal of Bioscience and Bioengineering 1999;88 178-182.

[190] Sutherland I.W. Polysaccharides for microbial exopolysaccharides. Carbohydrate Polymer 1999;38 319-328.

[191] Mesomo M., Silva M.F., Boni G., Padilha F.F., Mazutti M., Mossi A., de Oliveira D., Cansian R.L., Di Luccio M., Treichela H. Xanthan gum produced by Xanthomonas campestris from cheese whey: production optimisation and rheological characterization. J. Science Food Agric. 2009;89 2440-2445.

[192] Nitschke M., Rodrigues V., Schinatto L.F. Formulacao de meios de cultivo a base de soro de leite para a producao de goma xantana por X. campestris C7L. Cienc. Tecnol. Alim. 2001;21 82-85.

[193] Silva M.F., Fornari R.C.G., Mazutti M.A., Oliveira D., Padilha F.F., Cichoski A.J. Production and characterization of xantham gum by Xanthomonas campestris using cheese whey as sole carbon source. J. Food Eng. 2009;90 119-123.

[194] Vaningelgem F., Zamfir M., Adriany T., De Vuyst L. Fermentation conditions affecting the bacterial growth and exopolysaccharide production by Streptococcus thermophilus ST 111 in milk-based medium. Journal of Applied Microbiology 2004;97 12571273. 
[195] Bergmaier D., Champagne C.P., Lacroix C. Growth and exopolysaccharide production during free and immobilized cell chemostat culture of Lactobacillus rhamnosus RW-9595M D. Journal of Applied Microbiology 2005;98 272-284.

[196] Beshkova D., Frengova G. Bacteriocins from lactic acid bacteria: Microorganisms of potential biotechnological importance for the dairy Industry. Eng. Life Sci. 2012;12(4) $1-14$.

[197] Luchansky J. B. Overview on applications for bacteriocin-producing lactic acid bacteria and their bacteriocines. Antonie van Leeuwenhoek 1999;76 335.

[198] Ross R.P., Galvin M., McAuliff O., Morgan S.M., Ryan M.P., Twomey D.P., Meaney W.J., Hill C. Developing applications for lactococcal bacteriocins. Antonie van Leeuwenhoek 1999;76 337-346.

[199] Cheigh C.-I., Pyun Y.-R., Nisin biosynthesis and its properties. Biotechnology Letters. 2005;27 1641-1648.

[200] Cleveland J., Montville T. J., Nes I. F., Chikindas M. L. Bacteriocins: safe, natural antimicrobials for food preservation. International J. Food Microbiology 2001;71 1-20.

[201] Messens W., De Vuyst L. Inhibitory substances produced by lactobacilli isolated from sourdoughs - a review. International J. Food Microbiology 2002;72 31-43.

[202] Neysen P., De Vuyst L. Kinetic and modeling of sourdough lactic bacteria. Trends Food Science Technology 2005;16 95-103.

[203] Delgado A., Brito D., Peres C., Arroyo-Lopez F.N., Garrido-Fernandez A. Bacteriocin production by Lactobacillus pentosus $\mathrm{B} 96$ can be expressed as a function of temperature and $\mathrm{NaCl}$ concentration. Food Microbiology 2005;22 521-528.

[204] Juncioni de Arauz L., Jozala A. F., Pinheiro G.S., Gava Mazzola P., Pessoa A. Junior, Vessoni Penna T.C. Nisin expression production from Lactococcus lactis in milk whey medium. Chemical Technology Biotechnology 2008;83 325-328.

[205] Gonzalez-Toledo S.Y., Dominguez-Dominguez J., Garcia-Almendarez B.E., PradoBarragan L.A., Regalado-Gonzalez C. Optimization of Nisin Production by Lactococcus lactis UQ2 Using Supplemented Whey as Alternative Culture Medium. Journal of Food Science 2010;75(6) M347-M353.

[206] Liu X., Chung Y.K., Yang S.T., Yousef A.E. Continuous nisin production in laboratory media and whey permeate by immobilized Lactococcus lactis. Process Biochemistry. 2005;40 13-24.

[207] Juncioni de Arauz L., Jozala A.F., Baruque-Ramos J., Gava Mazzola P., Pessoa A. Junior, Vessoni Penna T.C. Culture medium of diluted skimmed milk for the production of nisin in batch cultivations. Ann. Microbiol. 2012;62 419-426.

[208] Juncioni de Arauz L., Jozala A. F., Gava Mazzola P., Vessoni Penna T.C. Nisin biotechnological production and application: a review. Trends in Food Science \& Technology 2009;20 146-154. 
[209] Guerra N.P., Rua M.L., Pastrana L. Nutritional factors affecting the production of two bacteriocins from lactic acid bacteria on whey. International J. Food Microbiology 2001;70 267-281.

[210] Bertrand N., Fliss I., Lacroix C. High nisin-Z production during repeated-cycle batch cultures in supplemented whey permeate using immobilized Lactococcus lactis UL719. International Dairy Journal. 2001;11 953-960.

[211] Desjardins P., Meghrous J., Lacroix C. Effect of aeration and dilution rate on nisin Z production during continuous fermentation with free and immobilized Lactococcus lactis UL719 in supplemented whey permeate. International Dairy Journal 2001;11 943-951.

[212] Abriouel H., Franz C.M.A.P., Omar N.B., Galvez A. Diversity and applications of Bacillus bacteriocins FEMS Microbiol. Review. 2011;35 201-232

[213] Cladera-Olivera F., Caron G.R., Brandelli A. Bacteriocin production by Bacillus licheniformis strain P40 in cheese whey using response surface methodology. Biochemical Engineering J. 2004;21 153-58.

[214] Guerra N.P., Fajardo Bernardez P., Pastrana Castro L. Fed-batch pediocin production on whey using different feeding media. Enzyme and Microbial Technology 2007;41 397-406

[215] Ghaly A.E., Kamal M.A. Submerged yeast fermentation of acid cheese whey for protein production and pollution potential reduction. Water Research 2004;38 631-644.

[216] Ghaly A.E., Kamal M., Correia L.R. Kinetic modelling of continuous submerged fermentation of cheese whey for single cell protein production. Bioresource Technology 2005;96 1143-1152.

[217] de Palma Revillion J.P., Brandelli A., Záchia Ayub M.A. Production of yeast extract from whey using K. marxianus. Braz. Arch. Biol. Technol. 2003;46(1) 121-127.

[218] Gardner D. New technologies in the conversion of whey to high protein products. Mod. Dairy 1989; 68 15-17.

[219] Champagne C.P., Gioulet J., Lachance R.A. Production of baker's yeast in cheese whey ultrafiltrate. Applied Environmental Microbiology 1990;56 425-430.

[220] Sandhu D.K., Waraich M.K. Conversion of cheese whey to single-cell protein. Biotechnology Bioengineering. 1983;25 797-803.

[221] Schultz N., Chang L., Hauck A., Reuss M., Syldatk C. Microbial production of singlecell protein from deproteinized whey concentrates. Applied Microbiology Biotechnology 2006;69 515-520.

[222] Vigliengo E., Reinheimer J. Use of whey and buttermilk based media to obtain biomass of thermophilic LAB. International J. of Dairy Technology 2009;62(3) 431-437.

[223] Aguirre-Ezkauriatza E.J., Aguilar-Yáñez J.M., Ramírez-Medrano A., Alvarez M.M. Production of probiotic biomass (Lactobacillus casei) in goat milk whey: Comparison 
of batch, continuous and fed-batch cultures. Bioresource Technology 2010;101 28372844.

[224] Koutinas A.A., Athanasiadis I., Bekatorou M., Iconomopoulou G. Blekas Kefir Yeast Technology: Scale-Up in SCP Production Using Milk Whey. Biotechnology and Bioengineering 2005;89(7) 788-796.

[225] Ykema A., Kater M. M., Smit H. Lipid production in whey permeate by an unsaturated fatty acid mutant of the oleaginous yeast Apiotrichum curvatum. Biotechnology Letters 1989;11 477-482.

[226] Fakas S., Papanikolaou S., Batsos A., Galiotou-Panayotou M., Mallouchos A., Aggelis G. Evaluating renewable carbon sources as substrates for single cell oil production by Cunninghamella echinulata and Mortierella isabellina. Biomass \& Bioenergy 2009; 33(4) 573-580.

[227] Vamvakaki A.N., Kandarakis I., Kaminarides S., Komaitis M., Papanikolaou S. Cheese whey as a renewable substrate for microbial lipid and biomass production by Zygomycetes. Engeneering Life Science 2010;10(4) 348-360.

[228] Bansal S., Oberoi H.S., Dhillon G.S., Patil R.T. Production of $\beta$ - galactosidase by Kluyveromyces marxianus MTCC 1388 using whey and effect of four different methods of enzyme extraction on $\beta$ - galactosidase activity. Indian J. Microbiology 2008;48 337341.

[229] Panesar P.S., Panesar R., Singh R.S., Kennedy J.F., Kumar H. Microbial production, immobilization and applications of $\beta$-D-galactosidase. J. Chemical Technology Biotechnology 2006;81 530-543.

[230] Ramirez-Matheus A.O., Rivas N. Production and partial characterization of $\beta$-galactosidase from Kluyveromyces lactis grown in deproteinized whey. Arch. Latinoam. Nutr. 2003;53194-201.

[231] Ramana-Rao M.V., Dutta S.M. Production of betagalactosidase from Streptococcus thermophiles grown in whey. Applied Environmental Microbiology 1977;34 185-188.

[232] Vasiljevic T., Jelen P. Production of $\beta$-galactosidase for lactose hydrolysis in milk and dairy products using thermophilic lactic acid bacteria. Innov. Food Sci. Emerg. Technol. 2001;2 75-85

[233] Rech R., Ayub M.A.Z. Simplified feeding strategies for fed-batch cultivation of Kluyveromyces marxianus in cheese whey. Process Biochemistry 2007;42 873-877.

[234] De Leon-Rodriguez A., Rivera-Pastrana D., Medina-Rivero E., Flores-Flores J.L., Estrada-Baltazar A., Ordonez-Acevedo L.G., Barba de la Rosa A.P. Production of penicillin acylase by a recombinant Escherichia coli using cheese whey as substrate and inducer. Biomolecular Engineering 2006;23 299-305. 
[235] Romero F.J., Garcıa L.A., Salas J.A., Diaz M., Quiros L.M. Production, purification and partial characterization of two extracellular proteases from Serratia marcescens grown in whey. Process Biochemistry 2001;36 507-515

[236] Ustariz F., Laca A., Garcia L.A., Diaz M. Mixed cultures of Serratia marcescens and Kluyveromyces fragilis for simultaneous protease production and COD removal of whey. J. of Applied Microbiology 2007;103 864-870. 